\title{
Towards an improved organic carbon budget for the western Barents Sea shelf
}

\author{
I. Pathirana ${ }^{1,2}$, J. Knies ${ }^{1,3}$, M. Felix ${ }^{4}$, and U. Mann ${ }^{4, *}$ \\ ${ }^{1}$ Geological Survey of Norway, 7491 Trondheim, Norway \\ ${ }^{2}$ University of Troms $\varnothing$, Department of Geology, 9011 Troms $\varnothing$, Norway \\ ${ }^{3}$ Centre for Arctic Gas Hydrate, Environment and Climate, University of Troms $\varnothing, 9037$ Troms $\varnothing$, Norway \\ ${ }^{4}$ SINTEF Basin Modelling Department, 7465 Trondheim, Norway \\ * currently at: Statoil Research Center, Arkitekt Ebbells veg 10, 7005 Trondheim, Norway
}

Correspondence to: I. Pathirana (irene.pathirana@ngu.no)

Received: 29 July 2013 - Published in Clim. Past Discuss.: 27 August 2013

Revised: 3 February 2014 - Accepted: 7 February 2014 - Published: 21 March 2014

\begin{abstract}
There is generally a lack of knowledge on how marine organic carbon accumulation is linked to vertical export and primary productivity patterns in the Arctic Ocean. Despite the fact that annual primary production in the Arctic has increased as a consequence of shrinking sea ice, its effect on flux, preservation, and accumulation of organic carbon is still not well understood. In this study, a multi-proxy geochemical and organic-sedimentological approach is coupled with organic facies modelling, focusing on regional calculations of carbon cycling and carbon burial on the western Barents Shelf between northern Scandinavia and Svalbard. OF-Mod 3 -D, an organic facies modelling software tool, is used to reconstruct and quantify the marine and terrestrial organic carbon fractions and to make inferences about marine primary productivity changes across the marginal ice zone (MIZ). By calibrating the model against an extensive set of sediment surface samples, we improve the Holocene organic carbon budget for ice-free and seasonally ice-covered areas in the western Barents Sea. The results show that higher organic carbon accumulation rates in the MIZ are best explained by enhanced surface water productivity compared to ice-free regions, implying that shrinking sea ice may reveal a significant effect on the overall organic carbon storage capacity of the western Barents Sea shelf.
\end{abstract}

\section{Introduction}

Despite the undisputed role of the Arctic Ocean in the modern climate system, the Arctic has only recently attracted significant attention, as the public has become aware that ongoing, fundamental change in the Arctic cryosphere could be a response to global warming (IPCC, 2007). The changes in the cryosphere are shown in enhanced loss in multi-year sea ice, snow cover and permafrost thawing. The effects of these dramatic changes on the biogeochemical cycle in the Arctic Ocean and particularly on its adjacent shelf areas are currently a matter of intense discussion (Serreze et al., 2007; Wassmann et al., 2006a, 2011; Arrigo et al., 2012). For instance, the continental shelves of the Arctic Ocean are important components of the global carbon cycle and may be responsible for $7-11 \%$ of the global carbon sequestration in the ocean (Hedges and Keil, 1995; Stein and Macdonald, 2004b).

A proper quantitative understanding of past organic carbon storage capacity and future changes under variable physical conditions (less or no sea ice) is therefore important. The Barents Sea, for example, is regarded as one of the most productive Arctic Ocean shelf seas that supports one of the world's richest fisheries (Sakshaug and Kovacs, 2009). The application of coupled physical and biological ocean models in the Barents Sea (Slagstad et al., 1999; Wassmann et al., 2006b) reveals average annual gross primary production estimates ranging from $20 \mathrm{gC} \mathrm{m}^{-2} \mathrm{yr}^{-1}$ in the seasonally ice-covered northern part to $>150 \mathrm{gC} \mathrm{m}^{-2} \mathrm{yr}^{-1}$ in the 
Atlantic water influenced southern Barents Sea (Wassmann et al., 2010). Modelling of gross primary productivity estimates with variable sea ice coverage in the Barents Sea shows that a decrease in ice cover and increase in surface water temperature will lead to an increase in production in the northern Barents Sea area up to $100 \mathrm{gC} \mathrm{m}^{-2} \mathrm{yr}^{-1}$, while production in the southern Atlantic water region will decrease by $15-25 \%$ (Ellingsen et al., 2008; Slagstad et al., 2011). To date, the highest variability is found in the marginal ice zone (MIZ, 50-> $100 \mathrm{gC} \mathrm{m}^{-2}$, Wassmann et al., 2010). Vertical carbon fluxes are highly variable (Olli et al., 2002; Reigstad et al., 2008, 2011) and pelagic-benthic coupling in the region is strong (Wassmann et al., 2006a). Annually approximately $32 \mathrm{gC} \mathrm{m}^{-2} \mathrm{yr}^{-1}$ (Arctic Water) to $44 \mathrm{gC} \mathrm{m}^{-2} \mathrm{yr}^{-1}$ (Atlantic Water) is exported below $90 \mathrm{~m}$ (Reigstad et al., 2008).

Maps of organic carbon content in surface sediments (Knies and Martinez, 2009) show the highest concentration of total organic carbon in the MIZ ( $>2 \mathrm{wt} . \%$ ) and lowest organic carbon concentration in the southern Barents Sea ( $<1 \mathrm{wt} . \%)$. In situ produced marine organic matter mainly controls the organic carbon content in the ice-free region. However, due to the proximity to the MIZ and in turn transfer of large amounts of land-derived inorganic and organic matter through melting sea ice, organic matter deposited in the shelf sediments below the MIZ comprises mixtures of marine (autochthonous) and terrestrial (allochthonous) sources (Vetrov and Romankevich, 2004; Winkelmann and Knies, 2005; Knies and Martinez, 2009). Hence, in order to provide a robust mass balance and eventually inferences on $\mathrm{CO}_{2}$ sequestration for past and future environmental scenarios, a geochemical characterisation of its multiple potential sources is essential.

Additionally, the maps of organic carbon content in surface sediments and organic carbon accumulation in the central and eastern Barents Sea presented by Vetrov and Romankevich (2004) were based on a large sample database and constructed accounting for topography, grain size and hydrographic conditions. This approach, however, lacks direct links to the sources and supply of the organic matter. Linking sedimentary data to physical and biological parameters on a regional scale can be done with a numerical model. While coupled physical and biological models predict modern and future productivity in the Barents Sea (cf. Ellingsen et al., 2008) and elsewhere (Wassmann et al., 2006a), basin modelling tools exist that are used to backcalculate possible ranges of past surface water productivity in relation to organic carbon content in the sediment and are used to identify and quantify potential petroleum source rocks (e.g. Schwartzkopf, 1993; Knies and Mann, 2002). One of these models is OF-Mod 3-D, a predictive, process-based, forward-modelling tool to calculate organic matter deposition and preservation on a 3-D grid throughout the modelled domain (Mann and Zweigel, 2008). One caveat is, however, that for ancient deposits not all input parameters are well constrained, and calibration of the models and evaluation of the results is difficult (Tommerås and Mann, 2006; Mann and Zweigel, 2008). With modern sedimentary data, close calibration can be achieved and information about the input and modelled parameters inferred.

The main objective of the present study is to investigate the impact of environmental changes in the Arctic on flux, preservation, and accumulation of organic carbon in the Barents Sea over the past $10000{ }^{14} \mathrm{C}$ yr BP. By introducing OFMod 3-D as a tool for (sub-)recent sediment studies, we provide a regional picture of the (marine and terrigenous) organic carbon fractions and marine paleoproductivity changes in the MIZ beyond core control. Further, by improving regional calculations of organic carbon burial in the western Barents Sea, we provide new baseline knowledge on the Holocene organic carbon budget for one of the most productive Arctic Ocean shelves. Unlike other efforts providing estimates of organic carbon mass balance based on organic source estimates from low-resolution sample grids (Stein and Macdonald, 2004b; Kuzyk et al., 2009), the importance of the present study builds on a well-constrained organic facies model with a grid size of $625 \mathrm{~km} \times 1000 \mathrm{~km}$ resolving $10000 \mathrm{yr}$ in 15 vertical layers that is calibrated against a comprehensive and analytically consistent characterization of sedimentary organic matter across the MIZ in the western Barents Sea. This approach provides new constraints on the effect of variable sea ice cover on the organic carbon storage capacity of a high productive Arctic shelf region. By applying different chronological constraints on a selected set of sediment cores across the MIZ, we (1) validate a Holocene thickness map inferred from seismic interpretation (Gurevich 1995), (2) calibrate the organic facies model for estimation and quantification of terrigenous and marine organic matter supply as well as marine primary productivity, and (3) finally discuss the accumulation rates of various organic matter sources and their burial on the western Barents shelf.

\section{Study region}

This study is carried out in the western Barents Sea between northern Norway and Svalbard including the shelf edge region. Figure 1 gives an overview of the study region, including the surface currents, ice extent, and locations of the sediment samples. There are two bathymetric highs: Bear Island and Spitsbergen Bank, where water depth is $<30 \mathrm{~m}$ at its shallowest point. There are two deeper channels in this region, Bear Island Trough (ca. $500 \mathrm{~m}$ deep) south of Bear Island and Storfjorden Trough (ca. $250 \mathrm{~m}$ deep) south of Svalbard.

A detailed description of the water masses and circulation regime can be found in Loeng (1991). The North Atlantic Drift brings warm, saline Atlantic water (AW) into the Barents Sea from the southwest flowing northward along the shelf and branching out eastward into Bear Island Trough. Cold, fresh Arctic water (ArW) enters the Barents Sea from 


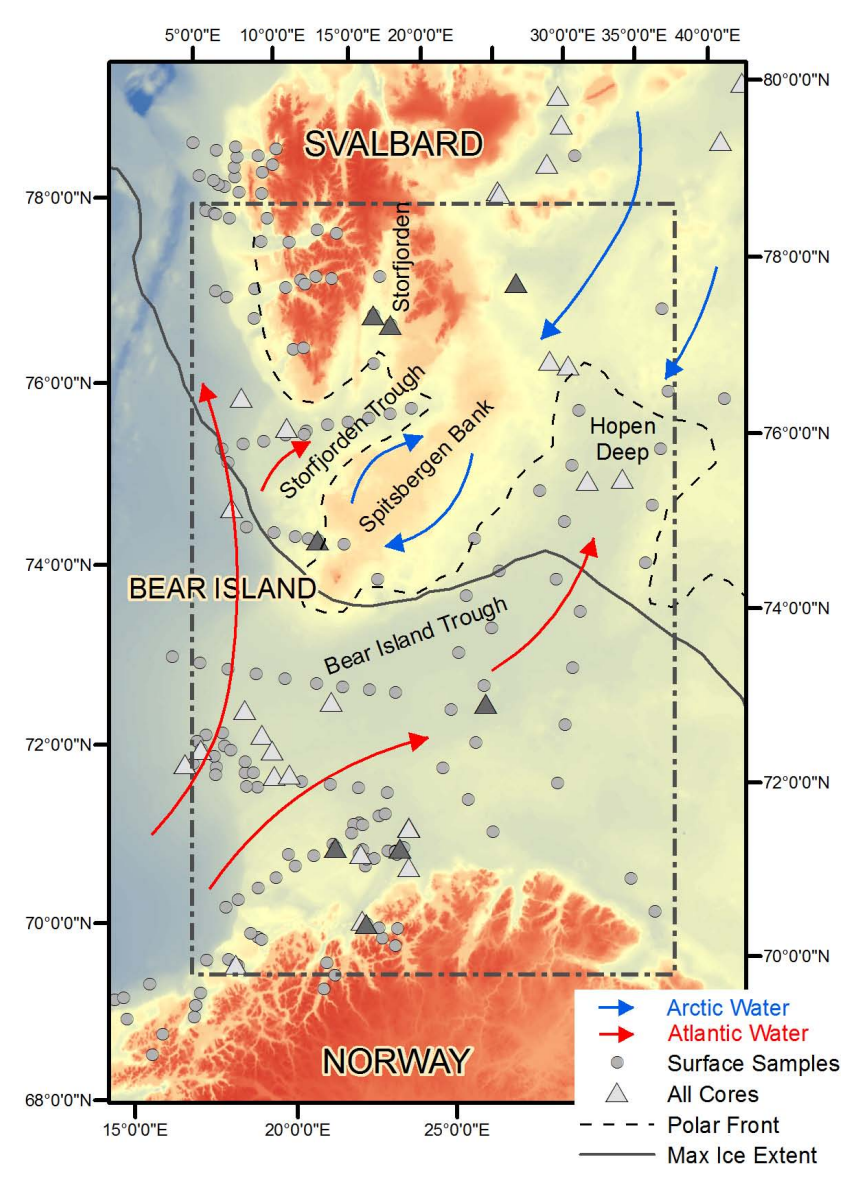

Fig. 1. Surface circulation, after Loeng (1991) (red = Atlantic water, blue $=$ Arctic water), Polar Front $(-)$, and maximum ice extent $(-)$ in the western Barents Sea. The modelled region (.-), locations of the surface samples (circles), and sediment cores (triangles) in the region (dark triangles $=$ used in the model) are indicated.

the northeast and flows southwestward along the flanks of Spitsbergen Bank. The ArW from the northeast and the AW from the southwest are separated by a density barrier, the Polar Front (PF). Its position is mainly topographically controlled following the $250 \mathrm{~m}$ isobaths (Loeng, 1991), but also depends on the relative strengths of the two water masses. The northern part of this region is partially covered by sea ice in the winter. Melting of the ice in spring and summer together with increased insolation and heat leads to a stratified water column that induces a phytoplankton bloom that follows the receding ice edge northward (Sakshaug and Skjoldal, 1989).

Also shown in Fig. 1 and all following maps is the maximum southernmost ice extent in the western Barents Sea over the last $250 \mathrm{yr}$ to distinguish between the ice-influenced northern and ice-free southern part of the study region. Based on the March through August ice edge positions in the Nordic Seas 1750-2002 data set by Divine and Dick (2007), the ice edge is defined as the outer boundary for $30 \%$ ice concentration. Monthly mean ice edge positions for the years 1750
2002 were compared and the maximum southernmost extent determined. The location of the maximum southernmost ice extent constructed in this way corresponds closely to the maximum sea ice extent in Navarro-Rodriguez et al. (2013) based on NSID and Met Office Hadley Centre ice charts.

\section{Material and methods}

\subsection{Geochemical and sedimentological analysis}

The calibration data set consists of 190 surface sediment samples (described in Knies and Martinez (2009) and additional samples) and 6 short sediment cores (ca. $30-40 \mathrm{~cm}$ ) representing the last 50-3000 yr (locations shown in Fig. 1, data available at http://doi.pangaea.de/10.1594/PANGAEA. 817232). The material was collected during various cruises between 2001 and 2006 (Winkelmann and Knies, 2005; Knies et al., 2006; Jensen et al., 2007; Knies and Martinez, 2009; www.mareano.no). All cores were taken with multicorer equipment. Undisturbed surfaces of all short cores (first centimetre of core depth) were sampled and stored at $-20^{\circ} \mathrm{C}$ until analysis. Thereafter, all samples were freeze-dried and homogenised prior to analyses. Details of the applied analytical techniques are described in Knies et al. (2006) and Jensen et al. (2007). A brief overview of the geochemical methods for new samples in this study is given below.

Grain size was measured on freeze-dried samples by wet sieving (size fraction $>2 \mathrm{~mm}$ diameter) and Coulter counter laser diffraction $(<2 \mathrm{~mm}$ diameter) on a Coulter LS 2000. Grain size distribution was determined as a volume percent assuming uniform density. The grain size is reported here as a sand fraction, where sand was defined as any material with a diameter $>63 \mu \mathrm{m}$, so sand fraction $=1$ means only coarse material $>63 \mu \mathrm{m}$ while sand fraction $=0$ means only material $<63 \mu \mathrm{m}$.

Total organic carbon (TOC in weight percent, wt.\%) was determined using a LECO CS 244 analyser. Aliquots $(200 \mathrm{mg}$ or $500 \mathrm{mg}$ ) of the samples were treated with $10 \%$ (volume) hydrochloric acid $(\mathrm{HCl})$ at $60^{\circ} \mathrm{C}$ to remove carbonate and washed with distilled water to remove excess $\mathrm{HCl}$. Possible loss of organic material due to acid leaching is not taken into account.

Stable isotope ratios of the organic carbon fraction $\left({ }^{13} \mathrm{C}_{\text {org }}\right)$ and the nitrogen fractions were determined by elemental analyser isotope ratio mass spectrometry (EAIRMS) on a Europa Scientific RoboPrep-CN elemental analyser by Iso-Analytical, Crewe, UK, following the procedure described in Knies et al. (2007). $\delta^{13} \mathrm{C}_{\text {org }}$ was determined on decarbonated samples. Total nitrogen was determined on aliquots of freeze-dried, homogenised samples, while inorganic nitrogen was determined on $\mathrm{KOBr}-\mathrm{KOH}$ treated aliquots following Silva and Bremner (1966). Twenty percent of the samples were measured in duplicate. Organic 
nitrogen was calculated as the difference between total nitrogen and inorganic nitrogen.

\subsection{Endmember mixing model}

To distinguish between marine and terrestrial organic matter, representative endmember values for marine and terrestrial material need to be assigned for defining a two-endmember mixing model typically using total organic carbon (TOC) and nitrogen content, kerogen microscopy, stable isotopes of organic matter $\left(\delta^{13} \mathrm{C}_{\text {org }}\right)$, Rock Eval pyrolysis (hydrogen index), or various biomarker data in the sediments (see e.g. Jasper and Gagosian, 1990; Stein, 1991; Stein and Macdonald, 2004a; Knies et al., 2007; Mann and Zweigel, 2008). In this study we use $\delta^{13} \mathrm{C}_{\text {org }}$ and the percentage of organic nitrogen contained in a sample to quantify the proportions of marine and terrestrial organic carbon.

$\delta^{13} \mathrm{C}_{\mathrm{org}}$ has been shown to be a reliable proxy for determining the proportion of terrestrial organic matter in Arctic marine sediments (e.g. Schubert and Calvert, 2001; Knies and Martinez, 2009). Typical values for C3 plant-derived terrestrial organic $\delta^{13} \mathrm{C}_{\text {org }}$ at high latitudes are -25.5 to $-29.3 \%$, with an average of $-27 \%$. The addition of $\mathrm{C} 4$ organic matter is less important in these regions (see e.g. Stein and Macdonald, 2004a; Knies and Martinez, 2009 for further references). The marine $\delta^{13} \mathrm{C}_{\mathrm{org}}$-derived endmember values in the Spitsbergen/Barents Sea region ranges between -20.3 and $-21 \%$ (Winkelmann and Knies, 2005; Knies and Martinez, 2009).

Knies and Martinez (2009) showed that the marine nitrogen endmember is represented by its organic fraction, i.e. $\% \mathrm{~N}_{\text {org }}($ of total $)=100 \%$, whereas the terrestrial nitrogen component is likely composed of a mixture of organic and inorganic nitrogen bound as ammonium in the clay matrix and/or supplied by soil (terrestrial) organic matter (Winkelmann and Knies, 2005; Knies and Martinez, 2009). The latter is supported by Knies et al. (2007), showing that the inorganic fraction of the total nitrogen content in surface sediments off Spitsbergen can be used as a proxy for terrestrial organic matter input. Furthermore, Mann et al. (2009) compared the percentage of inorganic nitrogen $\left(\% \mathrm{~N}_{\text {inorg }}=100\right.$ $\% \mathrm{~N}_{\text {org }}$ ) to the hydrogen index and maceral data in central Arctic Ocean Paleogene deposits under the assumption that $\mathrm{N}_{\text {inorg }}$ in marine sediments is non-local, i.e. allochthonus and of terrestrial origin, and found that soil (terrestrial) organic matter contains ca. $30-100 \% \mathrm{~N}_{\text {inorg }}$.

This study uses the same $\delta^{13} \mathrm{C}_{\text {org }}$ endmembers as Knies and Martinez (2009). A linear regression analysis of $\delta^{13} \mathrm{C}_{\mathrm{org}}$ versus $\mathrm{N}_{\text {org }}$ /TOC gives a terrestrial $\delta^{13} \mathrm{C}_{\text {org }}$ endmember of $-26.1 \%$. A linear regression analysis of $\% \mathrm{~N}_{\text {org }}$ and $\delta^{13} \mathrm{C}_{\mathrm{org}}$ gives a marine $\delta^{13} \mathrm{C}_{\text {org }}$ endmember of $-20.1 \%$ at $100 \%$ $\mathrm{N}_{\text {org }}$ (Fig. 2a and b). For $\% \mathrm{~N}_{\text {org }}$, the marine endmember is defined as $100 \%$. To obtain the terrestrial $\% \mathrm{~N}_{\text {org }}$ endmember we follow a procedure analogous to Jasper and Gagosian (1990). According to Jasper and Gagosian (1990), typical
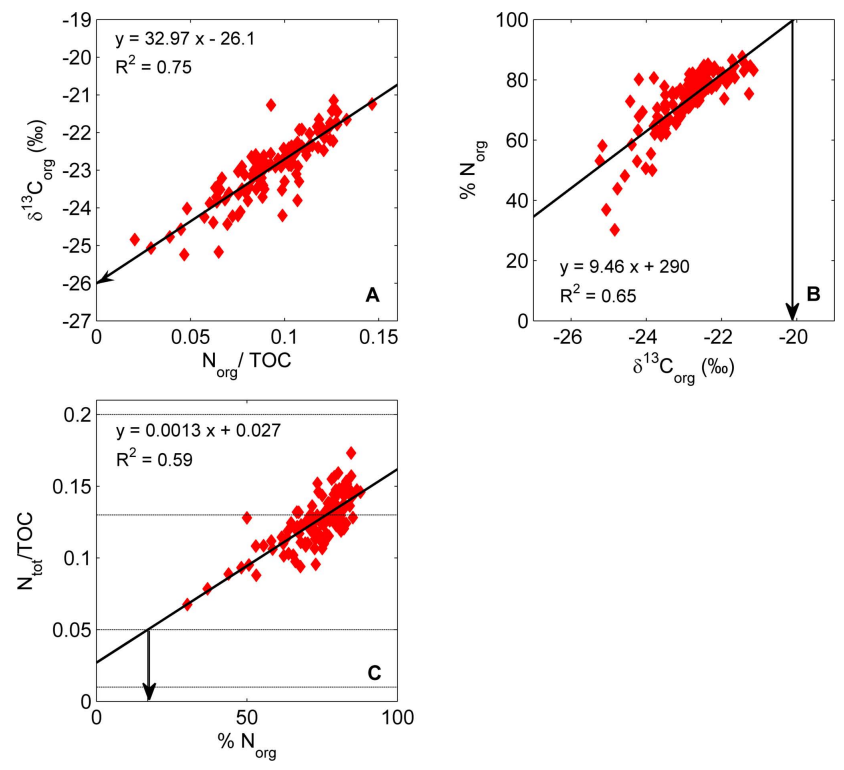

Fig. 2. (a) $\delta^{13} \mathrm{C}_{\text {org }}$ versus $\mathrm{N}_{\text {org }} / \mathrm{TOC}$ ratio to determine the terrestrial endmember $=-26.1 \%$. (b) $\% \mathrm{~N}_{\text {org }}$ versus $\delta^{13} \mathrm{C}_{\text {org }}$ to determine the marine endmember $=-20.1 \%$ (same plots as in Knies and Martinez, 2009). (c) Terrestrial $\% \mathrm{~N}_{\text {org }}$ endmember $=17 \%$ from $\mathrm{Nt}_{\mathrm{ot}} / \mathrm{TOC}$ versus $\% \mathrm{~N}_{\text {org }}$ after Jasper and Gagosian, 1990.

values of $\mathrm{N}_{\text {tot }} / \mathrm{TOC}$ for sediments of terrestrial origin are $0.01-0.05$, and $0.13-0.20$ for marine origin. In a regression of $\mathrm{N}_{\text {tot }} / \mathrm{TOC}$ versus $\% \mathrm{~N}_{\text {org }}$, we obtain the terrestrial $\% \mathrm{~N}_{\text {org }}$ endmember at $\mathrm{N}_{\text {tot }} / \mathrm{TOC}=0.05$ resulting in $\% \mathrm{~N}_{\text {org,terr }}=17 \%$ organic nitrogen (Fig. 2c). The latter supports the overall inference by Knies et al. (2007) that the inorganic proportions of the total nitrogen are applicable as a proxy for quantifying the terrestrial organic matter in the European sector of the Arctic.

\subsection{Age models and sedimentation rates}

Age models and sedimentation rates were determined by ${ }^{210} \mathrm{~Pb},{ }^{137} \mathrm{Cs}$ and/or AMS ${ }^{14} \mathrm{C}$ measurements. A list of cores pertaining to this study (BASICC1, BASICC8, St1245, R87MC006, R87MC006, R1MC85 and St20) and other published age data in the study region is provided in Table 1, together with the dating methods used to obtain the sedimentation rates. The age models for cores BASICC 1 and BASICC 8 are based on ${ }^{210} \mathrm{~Pb}$ measurements and are described in Vare et al. (2010). The age model for St1245 is based on ${ }^{137} \mathrm{Cs}$ and AMS ${ }^{14} \mathrm{C}$ measurements and is described in Winkelmann and Knies (2005). ${ }^{210} \mathrm{~Pb}$ measurements of cores R87MC006 and R1MC85 are described in Jensen et al. (2007, 2008). AMS ${ }^{14} \mathrm{C}$ measurements on cores R87MC006 and St20 were done on shells, shell fragments and foraminifera. The measurements were performed by the Chrono Centre, Queens University, Belfast, UK, and calibrated using the CALIB 6.02 software (Stuiver and Reimer, 1993) with the Marine09 
Table 1. Overview of sedimentation rates and dating methods in the western Barents Sea.

\begin{tabular}{|c|c|c|c|c|c|c|c|c|}
\hline Reference & Core & Lat $\mathrm{N}$ & Long E & $\begin{array}{l}\text { Water } \\
\text { depth }\end{array}$ & $\begin{array}{r}\text { Core } \\
\text { length }\end{array}$ & $\begin{array}{l}\text { Dating } \\
\text { method }\end{array}$ & $\begin{array}{r}\text { Average } \\
\text { LSR }\end{array}$ & $\begin{array}{l}\text { Holocene } \\
\text { thickness }\end{array}$ \\
\hline & & & & meter & meter & & $\left(\mathrm{cm} \mathrm{kyr}^{-1}\right)$ & Reported (m) \\
\hline This study & St20 & 74.82 & 18.02 & 296 & 0.27 & ${ }^{14} \mathrm{C}$ & 63 & - \\
\hline This study & R87MC006 & 71.31 & 20.32 & 240 & 0.21 & ${ }^{14} \mathrm{C} /{ }^{210} \mathrm{~Pb}$ & 4 & - \\
\hline Jensen et al. (2007) & R1MC85 & 70.46 & 21.68 & 466 & 0.22 & ${ }^{210} \mathrm{~Pb}$ & 210 & - \\
\hline Winkelmann and Knies (2005) & St1245 & 77.5 & 19.13 & 180 & 0.29 & ${ }^{14} \mathrm{C} /{ }^{137} \mathrm{Cs}$ & 187 & - \\
\hline Vare et al. (2010) & BASICC1 & 73.1 & 25.63 & 425 & 0.36 & ${ }^{210} \mathrm{~Pb}$ & 109 & - \\
\hline Vare et al. (2010) & BASICC8 & 77.98 & 36.8 & 135 & 0.32 & ${ }^{210} \mathrm{~Pb}$ & 103.5 & - \\
\hline Sarnthein et al. (2003) & $23258-3$ & 75 & 14 & 1768 & 0.4 & ${ }^{14} \mathrm{C}$ & 20.2 & - \\
\hline Sarnthein et al. (2003) & $23258-2$ & 75 & 14 & 1768 & 4.15 & ${ }^{14} \mathrm{C}$ & 39.1 & 2.5 \\
\hline Rasmussen et al. (2007) & JM02-460CG & 76.05 & 15.73 & 389 & 5.08 & ${ }^{14} \mathrm{C}$ & 30.5 & 4 \\
\hline Rasmussen et al. (2007) & JM02-460PC & 76.05 & 15.73 & 389 & 4.17 & ${ }^{14} \mathrm{C}$ & 35.7 & 4 \\
\hline Rasmussen et al. (2007) & JM03-373PC & 76.28 & 13.28 & 1485 & 3.6 & ${ }^{14} \mathrm{C}$ & 30.7 & 4 \\
\hline Risebrobakken et al. (2010) & PSh-5159N & 71.36 & 22.65 & 422 & 2.11 & ${ }^{14} \mathrm{C}$ & 10.9 & 1 \\
\hline Juntilla et al. (2010) & JM05-085GC & 71.62 & 22.93 & 408 & 4.87 & ${ }^{14} \mathrm{C}$ & 13.4 & 1 \\
\hline Juntilla et al. (2010) & JM07-01 & 70.5 & 21.5 & 440 & 5.84 & ${ }^{14} \mathrm{C}$ & 23.3 & 1 \\
\hline Juntilla et al. (2010) & JM07-02 & 71.16 & 23 & 402 & 3.37 & ${ }^{14} \mathrm{C}$ & 94.4 & 0.1 \\
\hline Rüther et al. (2011) & JM09-KA03 & 72.74 & 16.2 & 427 & 3.07 & ${ }^{14} \mathrm{C}$ & 10.8 & 0.1 \\
\hline Rüther et al. (2011) & JM08-0309 & 72.49 & 17.01 & 385 & 2.11 & ${ }^{14} \mathrm{C}$ & 4 & 0.1 \\
\hline Rüther et al.. (2011) & JM07-09 & 72.33 & 17.51 & 378 & 2.69 & ${ }^{14} \mathrm{C}$ & 6.7 & 0.3 \\
\hline Rüther et al.. (2011) & JM08-0306 & 72.99 & 19.52 & 416 & 2.12 & ${ }^{14} \mathrm{C}$ & 8.4 & - \\
\hline \multicolumn{9}{|l|}{ Carroll et al.. (2008/) } \\
\hline Zaborska et al.. (2008) & StI & 75.67 & 30.17 & 345 & 0.2 & ${ }^{210} \mathrm{~Pb} /{ }^{137} \mathrm{Cs}$ & 54.9 & - \\
\hline \multicolumn{9}{|l|}{ Carroll et al.. (2008/) } \\
\hline Zaborska et al.. (2008) & StIV & 77.02 & 29.48 & 222 & 0.2 & ${ }^{210} \mathrm{~Pb} /{ }^{137} \mathrm{Cs}$ & 36.9 & - \\
\hline \multicolumn{9}{|l|}{ Carroll et al.. (2008/) } \\
\hline Zaborska et al.. (2008) & StXVI & 77.08 & 28.55 & 206 & 0.2 & ${ }^{210} \mathrm{~Pb} /{ }^{137} \mathrm{Cs}$ & 41.5 & - \\
\hline \multicolumn{9}{|l|}{ Carroll et al.. (2008/) } \\
\hline Zaborska et al.. (2008) & StXVIII & 75.67 & 31.82 & 340 & 0.2 & ${ }^{210} \mathrm{~Pb} /{ }^{137} \mathrm{Cs}$ & 123 & - \\
\hline J. Knies (unpublished) & VM55 & 72.04 & 17.74 & 292 & 2.5 & ${ }^{14} \mathrm{C}$ & 5.2 & 0.65 \\
\hline J. Knies (unpublished) & VM73 & 72.08 & 18.28 & 310 & 2.7 & ${ }^{14} \mathrm{C}$ & 7.4 & 1 \\
\hline J. Knies (unpublished) & 06JM-012 & 71.62 & 22.93 & 432 & 4.58 & ${ }^{14} \mathrm{C}$ & 39 & 1 \\
\hline
\end{tabular}

Table 2. Uncorrected and calibrated radiocarbon ages used in this study; calibration based on the Marine09 and IntCal09 calibration curves (Reimer et al., 2009) and a $\Delta \mathrm{R}$ of 0.

\begin{tabular}{lrrrr}
\hline Core & \multicolumn{4}{c}{ Cal } \\
${ }^{14} \mathrm{C}$ yr BP & yr BP & $1 \sigma$ range & $2 \sigma$ range \\
\hline R87MC006, & & & & \\
$18.5 \mathrm{~cm}$ & $3831 \pm 37$ & 3776 & $3717-3835$ & $3668-3896$ \\
St20, $12.5 \mathrm{~cm}$ & $388 \pm 60$ & 412 & $428-506$ & $310-515$ \\
St20, $26 \mathrm{~cm}$ & $681 \pm 60$ & 622 & $634-680$ & $545-699$ \\
\hline
\end{tabular}

(R87MC006) and IntCa109 (St20) calibration curves (Reimer et al., 2009) and a $\Delta \mathrm{R}$ of 0 . Table 2 summarises these radiocarbon ages.

\subsection{OF-Mod 3-D model set-up}

OF-Mod 3-D (Organic Facies Model 3-D) simulates the deposition and burial of organic carbon on a basin scale, and is based on the interaction between inorganic and organic basin fill, as well as preservation of organic material. The organic part of the model is described in more detail in Mann and Zweigel (2008), while the basin fill modelling approach used here is different than in that paper. The inorganic basin fill is modelled based on the present-day depth and bathymetry maps. The lithology (sand fraction) distribution is calculated based on the spatial distribution of sedimentary facies (Felix et al., 2012). The sedimentary facies are determined with a set of fuzzy logic rules, where the facies are defined based on water depth and distance to shore (from the bathymetry maps). A sand fraction is assigned to each facies and the spatial distribution is calculated using Sugeno rules (e.g. Demicco and Klir, 2004). The facies rules are adjusted so that the modelled sand fraction values fit with the measured values.

To build the stratigraphic infill model, two bounding surfaces (top and bottom) were used. For the top surface the present day IBCAO bathymetry, Version 2.23 (Jakobsson 
Table 3a. OF-Mod 3-D input model set-up.

\begin{tabular}{lr}
\hline Inorganic parameters & Setting \\
\hline Origin X (UTM 35N, in m) & 75000 \\
Origin Y (UTM 35N, in m) & 7760000 \\
\# cells in X & 125 \\
\# cells in Y & 200 \\
Grid cell size (in m) & 5000 \\
\# vertical layers & 15 \\
Age top layer (in Ma) & 0 \\
Age bottom layer (in Ma) & 0.01 \\
Initial porosity sand (fraction) & 0.75 \\
Initial porosity shale (fraction) & 0.95 \\
DBD sand (in $\mathrm{g} \mathrm{cm}^{-3}$ ) & 2.65 \\
DBD shale (in $\mathrm{g} \mathrm{cm}^{-3}$ ) & 2.72 \\
\hline
\end{tabular}

et al., 2008), in this region was used. The bottom surface was constructed by combining the present day bathymetry with the thickness of Holocene sediments in this area (map by Gurevich, 1995), defining the Holocene as covering the last $10000 \mathrm{yr}$. Holocene sediment thickness in the southwestern Barents region (not covered by the Gurevich (1995) map) was inferred by extending the Gurevich (1995) map through calculating sediment package thicknesses from published sedimentation rates in the SW corner of the study region (Table 1). The model grid consists of $125 \times 200$ square cells and 15 vertical layers between $0 \mathrm{kyr}$ (top layer) and $10 \mathrm{kyr}$ (bottom layer), with a grid cell size of $5000 \mathrm{~m}$. Sedimentation rate is determined through decompaction of the present-day deposits, whose thickness is given in OF-Mod using present-day depth maps.

The organic carbon (OC) is split into three different fractions: marine (MOC), terrigenous $\left(\mathrm{C}_{\text {ter }}\right)$, and residual organic carbon. This results in a slightly different allocation of MOC and $\mathrm{C}_{\text {terr }}$ than the two-endmember approach used for the measured values because part of both fractions has been assigned to the residual fraction. The residual fraction needs to be taken into account in OF-Mod because otherwise it would not be possible to model the low hydrogen index values associated with degraded material. Input of terrigenous and residual organic carbon is given directly in weight percentage. Marine organic carbon deposition and burial is calculated from the carbon flux from primary productivity at the sea surface, combined with an equation for the burial efficiency of organic carbon at the seafloor.

$$
\begin{gathered}
\text { MOC }=\left(\frac{0.409 \mathrm{PP}^{1.41} \times z^{-0.63}}{10}\right) \\
\text { Burial efficiency } \\
\times\left(0.54-0.54 \times\left(\frac{1}{0.037 \times \mathrm{LSR}^{0.5}+1}\right)\right) \times\left(\frac{100}{\mathrm{DBD} \times \mathrm{LSR}}\right)
\end{gathered}
$$

Table 3b. OF-Mod 3-D input organic parameters.

\begin{tabular}{lr}
\hline Organic parameters & Setting \\
\hline PP coast (in $\mathrm{gC} \mathrm{m}^{-2} \mathrm{yr}^{-1}$ ) & 60 \\
Distance to open ocean (in $\mathrm{km}^{-1}$ & 50 \\
PP open ocean (in $\mathrm{gC}^{-2} \mathrm{yr}^{-1}$ ) & 35 \\
PP lens (North) (additional $\mathrm{gC}^{-2} \mathrm{yr}^{-1}$ ) & 50 \\
pTOC (in wt.\%) & 0.3 \\
pTOC lens 1 (Norway) (additional wt.\%) & 1.5 \\
pTOC lens 2 (Svalbard) (additional wt.\%) & 2.5 \\
Max pTOC at Sand (\%) & 75 \\
SOC (in wt.\%) & 0.1 \\
$\%$ Norg (marine, terrigenous, residual) & $100 ; 17 ; 83$ \\
$\delta^{13} \mathrm{C}_{\text {org }}(\%$ ) (marine, terrigenous, residual) & $-20.1 ;$ \\
\end{tabular}

The flux is described by the equation of Betzer et al. (1984), where the organic carbon flux to the sediment surface is in $\mathrm{gC} \mathrm{m}^{-2} \mathrm{yr}^{-1}, \mathrm{PP}=$ primary productivity $\left(\mathrm{gC} \mathrm{m}^{-2} \mathrm{yr}^{-1}\right)$, and $z=$ water depth $(\mathrm{m})$. The burial efficiency at the seafloor is calculated using the equation of Betts and Holland (1991), where LSR $=$ sedimentation rate $\left(\mathrm{cm} \mathrm{kyr}^{-1}\right)$ and $\mathrm{DBD}=$ sedimentary dry bulk density $\left(\right.$ in $\mathrm{g} \mathrm{cm}^{-3}$ ).

In addition, burial of all three types of organic carbon is lithology dependent: MOC and residual OC have higher preservation in finer grained deposits, while terrigenous OC tends to be preserved better in coarser grained deposits (Bergamaschi et al., 1997; Keil et al., 1998).

In OF-Mod the input of all three types of organic material is a combination of a basin-wide trend and local increased input. Here a low background PP $\left(35 \mathrm{gC} \mathrm{m}^{-2} \mathrm{yr}^{-1}\right)$ is used throughout the model region, and the processes related to the ice margin in the MIZ are represented by additional PP local input in the northern part $\left(50 \mathrm{gC} \mathrm{m}^{-2} \mathrm{yr}^{-1}\right)$ giving a total $\mathrm{PP}$ of $85 \mathrm{gC} \mathrm{m}^{-2} \mathrm{yr}^{-1}$ in this region. These PP values were calibrated to reproduce the TOC content of the surface sediments. A summary of the relevant input parameters is given in Table 3.

To evaluate the performance of the model in replicating the calibration data, a simple goodness-of-fit procedure between the measured sediment samples and the closest model grid points is employed on the sand fraction and TOC data. A linear regression between the residuals (absolute difference between the model and the measurements) and the measured data is minimised.

\section{Results and discussion}

\subsection{Validation of the Holocene thickness map in the Barents Sea}

Figure 3 shows the extended Holocene sediment thickness map and sediment thicknesses calculated for a number of core locations in the western Barents Sea (see Table 1 for sedimentation rates and references). Using these published 
sedimentation rates, together with other known sediment accumulation rates in the whole Barents Sea (Heldal et al., 2002; Zaborska et al., 2008; Boitsov et al., 2009; Maiti et al., 2010), the amount of sediment accumulated during the past $10000 \mathrm{yr}$ was calculated. Most calculated sediment thicknesses agree well with the map (Fig. 3). There are, however, a number of locations with very high calculated thickness values $(>10 \mathrm{~m})$. These seem unrealistic especially when taking compaction into account. When looking at the different dating methods, it becomes clear that overall those cores with AMS ${ }^{14} \mathrm{C}$ dates agree with the map and the reported thickness, whereas cores dated with other isotopes do not fit.

This study includes one core R87MC006 (see Table 1) that was dated with both AMS ${ }^{14} \mathrm{C}$ and ${ }^{210} \mathrm{~Pb}$. The sedimentation rate estimate of $\mathrm{R} 87 \mathrm{MC} 006$ from ${ }^{210} \mathrm{~Pb}$ is $80 \mathrm{~cm} \mathrm{kyr}^{-1}$ based on the top $5 \mathrm{~cm}$, which is within the ranges of published rates $\left(0.3-1.9 \mathrm{~mm} \mathrm{yr}^{-1} / 30-190 \mathrm{~cm} \mathrm{kyr}^{-1}\right)$ elsewhere in the Barents Sea (e.g. Heldal et al., 2002; Zaborska et al., 2008; Boitsov et al., 2009; Maiti et al., 2010). The sedimentation rate estimate from an $\mathrm{AMS}{ }^{14} \mathrm{C}$ date at $18.5 \mathrm{~cm}$ depth is $4 \mathrm{~cm} \mathrm{kyr}^{-1}$. These two estimates differ by an order of magnitude and the question arises how to interpret and if possible reconcile these two rates.

${ }^{14} \mathrm{C}$ has a much longer half-life (ca. $5600 \mathrm{yr}$ ) and is the suitable isotope for this date range. However, many short box and multicores, presumably representing the most recent past, are routinely dated only with ${ }^{210} \mathrm{~Pb}$ (half-life of $22.3 \mathrm{yr}$ ) or ${ }^{137} \mathrm{Cs}$ (half-life of ca. $30 \mathrm{yr}$ ) (e.g. Carroll et al., 2008; Kuzyk et al., 2009; Vare et al., 2010). The ${ }^{210} \mathrm{~Pb}$ content of a sediment is usually measured on the fine fraction of the sediment since it is particle reactive (Soetaert et al., 1996). On the other hand ${ }^{14} \mathrm{C}$ is measured on shells, shell fragments or foraminifera, which are generally much larger in diameter than the fine sediment. Thus ${ }^{210} \mathrm{~Pb}$ is comparatively more susceptible to processes happening within the sediment column, e.g. sediment mixing and bioturbation, than ${ }^{14} \mathrm{C}$ (Soetaert et al., 1996). Mixing of the sediment and bioturbation spread the particle reactive radioisotopes $\left({ }^{210} \mathrm{~Pb}\right.$ and also ${ }^{137} \mathrm{Cs}$ ) over a larger part of the sediment column than would be the case without disturbance and reduces the overall concentration of the isotope in the sediment (Johannessen and Macdonald, 2012). The depth at which the apparent ${ }^{210} \mathrm{~Pb}$ background concentration is determined is deeper and the resulting sedimentation rate higher than without any mixing. Thus ${ }^{210} \mathrm{~Pb}$ (and ${ }^{137} \mathrm{Cs}$ ) age and sedimentation rate estimates are always maximum limits (Johannessen and Macdonald, 2012).

When comparing ${ }^{210} \mathrm{~Pb}$ and $\mathrm{AMS}{ }^{14} \mathrm{C}$ age models of a core from the Sea of Japan, Crusius and Kenna (2007) concluded that under low sediment accumulation conditions, bioturbation and mixing may dominate the processes in the sediment column. In that case, ${ }^{210} \mathrm{~Pb}$ may be more indicative of mixing and bioturbation than sediment accumulation over a longer period of time.
The Quaternary sediment cover in the Barents Sea is generally thin (Elverhøi and Solheim, 1983; Vorren et al., 1989; Gurevich, 1995). The seafloor is hard and glacial features like ridges, moraines, or glacial lineations can be readily identified on high-resolution backscatter images (e.g. Vorren et al., 1989; Bellec et al., 2010; Winsborrow et al., 2010; Rüther et al., 2011). In many cases the reported thickness of Holocene sediments deposited since the last glaciation is less than $4 \mathrm{~m}$ (see examples in Table 2 and e.g. Elverhøi and Solheim, 1983; Gurevich, 1995; Rüther et al., 2011). Taking into account potentially missing core tops, $5 \mathrm{~m}$ of accumulated sediments in $10 \mathrm{kyr}$ results in a sedimentation rate of $50 \mathrm{~cm} \mathrm{kyr}^{-1}$ or $0.05 \mathrm{~cm} \mathrm{yr}^{-1}$ and only $10 \mathrm{~cm}$ of accumulated sediments in $200 \mathrm{yr}$, the applicable time span for ${ }^{210} \mathrm{~Pb}$. We believe that sedimentation rates estimated with ${ }^{210} \mathrm{~Pb}$ in the Barents Sea are exaggerated and the sedimentation conditions are better represented by AMS ${ }^{14} \mathrm{C}$ estimates.

As a result, only AMS ${ }^{14} \mathrm{C}$ sedimentation rates are considered reliable in this study. The sediment thicknesses calculated from $\mathrm{AMS}{ }^{14} \mathrm{C}$ sedimentation rates and the sediment thickness map (Gurevich, 1995) agree well. The extended Holocene sediment thickness map is accurate for the study region and sufficient for the purpose of this study.

\subsection{Calibration of the organic facies model}

\subsubsection{Inorganic sediment characteristics}

Sedimentation rates for the Holocene estimated from seismic data in the Barents Sea generally range from 1 to $100 \mathrm{~cm} \mathrm{kyr}^{-1}$, with higher rates (up to $500 \mathrm{~cm} \mathrm{kyr}^{-1}$ ) occurring in bathymetric deeper depressions, e.g. glacial troughs (Gurevich, 1995; Vetrov and Romankevich, 2004). This pattern corroborates AMS ${ }^{14} \mathrm{C}$-based LSR calculations in various sediment cores in the Barents Sea (Table 1) and confirms previous inferences of a relatively good agreement between seismic interpretation and AMS ${ }^{14} \mathrm{C}$-based chronologies of Holocene sequences (Elverhøi et al., 1989; Lebesbye, 2000). The core data indicate the highest LSR $\left(>75 \mathrm{~cm} \mathrm{kyr}^{-1}\right.$ ) occurring preferably in the glacial troughs (e.g. Bear Island Trough, Storfjorden Trough), in fjords (e.g. Storfjorden), and below the MIZ. Relatively low LSR is generally observed on shallow banks (e.g. Spitsbergen Bank, Tromsøflaket). Figure 4 shows the OF-Mod modelled LSR compared to LSR from sediment cores in the region. The modelled LSR agree particularly well with the ${ }^{14} \mathrm{C}$-dated cores in the southwestern Barents Sea. The mismatch between calculated and modelled LSR in northern Norwegian fjords is due to the large grid cell size for the coastal regions. For each grid cell one average value for the respective region is calculated. Grid cell size determines the area over which the average is calculated and therefore the resolution of the model. This model has a grid cell size of $5000 \mathrm{~m} \times 5000 \mathrm{~m}$. Large variability over a region smaller than that, including many fjords, is not reflected in the model outcome. Towards the MIZ, calculated LSR 


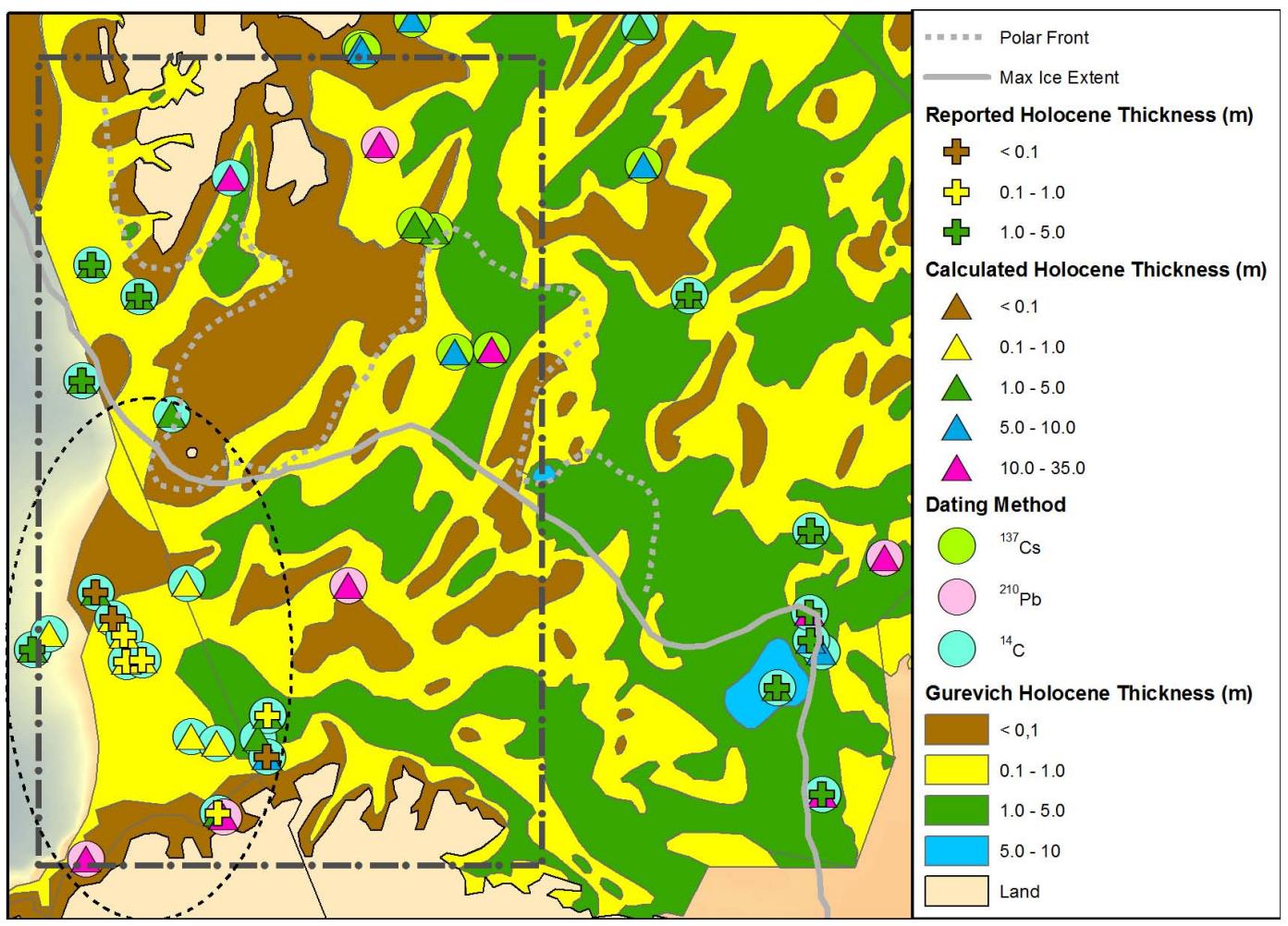

Fig. 3. Extended Holocene (10 kyr) sediment thickness map of the study area based on the map by Gurevich (1995). The extended area on the southwestern Barents shelf is indicated by the oval. Sediment thickness calculated from published sedimentation rates is indicated by the triangles and reported Holocene sediment thickness by crosses. The dating methods used to obtain sedimentation rates are shown by the circles and the modelled area outlined by the dash-dot line. See Table 1 for details.

from ${ }^{14} \mathrm{C}$ dated cores are slightly higher $\left(30-45 \mathrm{~cm} \mathrm{kyr}^{-1}\right)$ compared to the modelled LSR $\left(0-30 \mathrm{~cm} \mathrm{kyr}^{-1}\right)$, however still on the same order of magnitude. Generally, the modelled LSR follows the bathymetry in the Barents Sea, and is not controlled by the MIZ. Similar to the interpreted seismic data (Gurevich, 1995), the modelled LSR is highest in morphological depressions and fjords, the natural sediment depocenters in the western Barents Sea (Faleide et al., 1993). Hence, the resulting OF-Mod 3-D map (and thus the construction method of the Holocene bottom surface map used in OF-Mod 3-D) can be considered to represent a realistic view of the Holocene sedimentation rate for the entire study region.

Figure 5a shows the distribution of the measured sedimentary sand fraction (proportion of coarse material $>0.63 \mu \mathrm{m}$, with $0 \leq \mathrm{SF} \leq 1)$ compared to the modelling results. The measured sediment data show that most of the study region (east and north) consists of very fine material $(\mathrm{SF}<0.2)$, with the bulk of the coarser material found along the shelf break $(\mathrm{SF}>0.4)$ and in the coastal region north of Norway (SF 0.2-0.8). The sand-rich deposits along the shelf edge are believed to be relic facies originating from sediment supplied by the Barents ice sheet to the shelf edge during sea level low stands during the last glaciation and erosion and re-deposition during deglaciation (Vorren et al., 1989; Bøe et al., 2009). The deeper parts of Bear Island Trough are highly variable (SF $0.2-0.8$ ), whereas mainly fine-grained material accumulates in Storfjorden Trough. There are some single higher values (SF 0.4-0.6) in the southeast region and east of Svalbard. Spitsbergen Bank consists mainly of coarse carbonates (Elverhøi and Solheim, 1983; Węsławski et al., 2012). The modelled sand fraction replicates the calibration data quite well. Figure $5 \mathrm{~b}$ shows the regression analysis of the difference between the modelled SF and the measurements against the calibration data. The low correlation of the residuals compared to the measured values $\left(R^{2}=0.35\right)$ indicates a good fit between the model and the measured data. Figure $5 \mathrm{c}$ shows the spatial distribution of the residuals plotted on top of the modelled sand fraction. No spatial trend is visible in the distribution of the residual magnitudes. The fine sediment in Storfjorden Trough, coarser sediment in Bear Island Trough and coarse shelf break are represented well in the sand fraction model. The relic sand deposits are modelled through a separate facies but slightly overestimate the sand content. The model provides less detail north of the coastline of the Norwegian mainland and the modelled values are finer than the measured ones. This is due to resolution. The model resolution is coarser than the small-scale variations in 


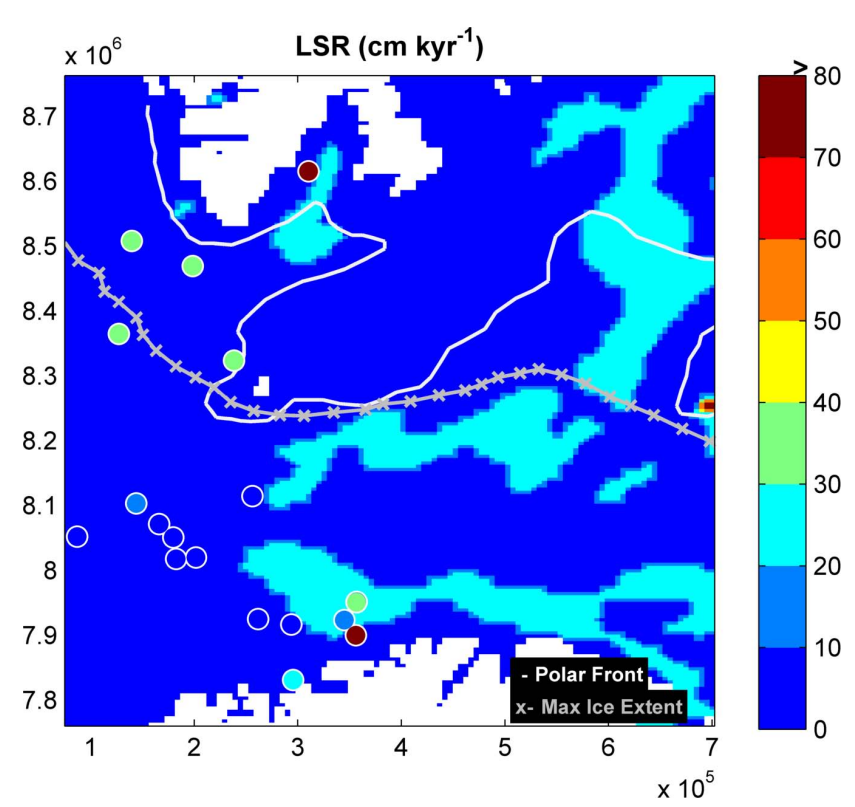

Fig. 4. OF-Mod 3-D modelled sedimentation rates $\left(\mathrm{cm} \mathrm{kyr}^{-1}\right)$ compared to published rates $\left({ }^{14} \mathrm{C}\right.$ only) in the area (circles). The modelled LSR agree particularly well with the ${ }^{14} \mathrm{C}$ dated cores in the southwestern Barents Sea. Generally, the modelled LSR follow the bathymetry in the Barents Sea, and are not controlled by the MIZ.

the point samples and the latter cannot be replicated in detail. The resulting modelled grain size map also agrees well with the sediment distribution map by Elverhøi (1984), which is based on seismic and sparker data and sediment samples. Overall the inorganic, stratigraphic part of the model provides a consistent framework for the organic modelling efforts.

\subsubsection{Organic matter characteristics}

In the following only the results for the top layer, i.e. the present-day/sediment surface, are discussed and compared to the surface sample data set. Figure 6a shows the TOC distribution of the measured surface sediment data compared to the model results. Figure $6 \mathrm{~b}$ shows the results of the goodness-of-fit test and Fig. 6c the spatial distribution of residual magnitudes plotted on top of the modelled TOC distribution. In general, the sediments exhibit a lower TOC content south of the MIZ (0.2-1.8wt.\% TOC) than within the MIZ, especially along the flanks of Spitsbergen Bank, and in the coastal regions (1.8-3 wt.\% TOC). The TOC content of the sediments is also low ( $<0.8 \mathrm{wt}$.\% TOC) along the shelf break. There are some higher values (1.3-1.8 wt.\%) upslope of Bear Island Trough. The OF-Mod results are in the same range $(0-<4$ wt.\% TOC) as the sediment samples and agree well with the observed (this study and Knies and Martinez, 2009) and previously published data (Stein et al., 1994; Vetrov and Romankevich, 2004). The regression between the residuals and the model results shows only a weak correla- tion $\left(R^{2}=0.2\right)$, indicating a good model fit. The higher TOC content in the north and in the MIZ is captured, as well as the highs along coasts and maximum values along the flanks of Spitsbergen Bank. The low TOC content south of the maximum ice extent and along the shelf break is represented well. The model slightly overestimates the TOC content north of the Norwegian coast compared to the calibration data due to coarse resolution. In addition the model underestimates the TOC content of the upslope part of Bear Island Trough. This is partly due to overestimates of sand content in this region and thus less modelled organic deposition. Another reason could be lateral transport of sediments downslope of Bear Island Trough after deposition, which OF-Mod 3-D does not include. This has recently been suggested as a possibility to explain the occurrence of the novel organic geochemical biomarker (IP25), likely biosynthesized by a limited number of sea ice diatoms during the spring bloom (Brown et al., 2011), in surface sediments of the Barents Sea south of the maximum ice extent (Navarro-Rodriguez et al., 2013).

According to Vetrov and Romankevich (2004), TOC in Barents Sea sediments is mainly composed of marine organic matter but with $\sim 30 \%$ of terrigenous origin. A predominantly marine source of the organic matter has been further confirmed by bulk geochemical analyses (Tamelander et al., 2006; Zaborska et al., 2008). The present study, however, reveals distinct spatial variability in both the amount and composition of the sedimentary organic carbon. The sediments exhibit low marine organic carbon (MOC) content south of the MIZ (0-1 wt.\%, Fig. 7) that presents $>90 \%$ of the total sedimentary organic fraction. In contrast, high MOC content $(1-2 \mathrm{wt} . \%)$ is found in the MIZ and in Storfjorden Trough. Maximum MOC occurs along the flanks of Spitsbergen Bank (1.3-2 wt.\%). OF-Mod reproduces the pattern of low MOC content in the south compared to the north and the maximum MOC content along Spitsbergen Bank well (Fig. 7). A goodness-of-fit analysis is not performed on the MOC data because of the different organic matter fraction allocation approaches (see Sect. 3.4). OF-Mod 3-D predicts the highest MOC content ( $>3 \mathrm{wt} . \%$ ) along the bottom of the southern flank of Spitsbergen Bank. These values are not fully reproduced by the measured MOC data $(<2 \mathrm{wt} . \%)$, most likely due to a higher annual variability of primary productivity distribution within the MIZ. Figure 8 shows the primary productivity distribution used as input in OF-Mod 3-D compared to three sediment cores. Calculation of primary productivity (in $\mathrm{gC} \mathrm{m}^{-2} \mathrm{yr}^{-1}$ ) for the core positions is based on the amount of MOC (wt.\%), dry bulk density (DBD in $\mathrm{g} \mathrm{cm}^{-3}$ ), linear sedimentation rate (LSR in $\mathrm{cm} \mathrm{kyr}^{-1}$ ) and water depth $(z$ in $\mathrm{m})$. To calculate the primary productivity from the core data, Eq. (1) was solved for PP (Knies and Mann, 2002, and references therein):

$\mathrm{PP}=\left(\frac{\mathrm{MOC} \cdot 0.378 \cdot \mathrm{DBD} \cdot \mathrm{LSR} \cdot z^{0.63}}{\left(1-\left(\frac{1}{0.037 \cdot \mathrm{LSR}^{1.5}+1}\right)\right)}\right)^{0.71}$. 

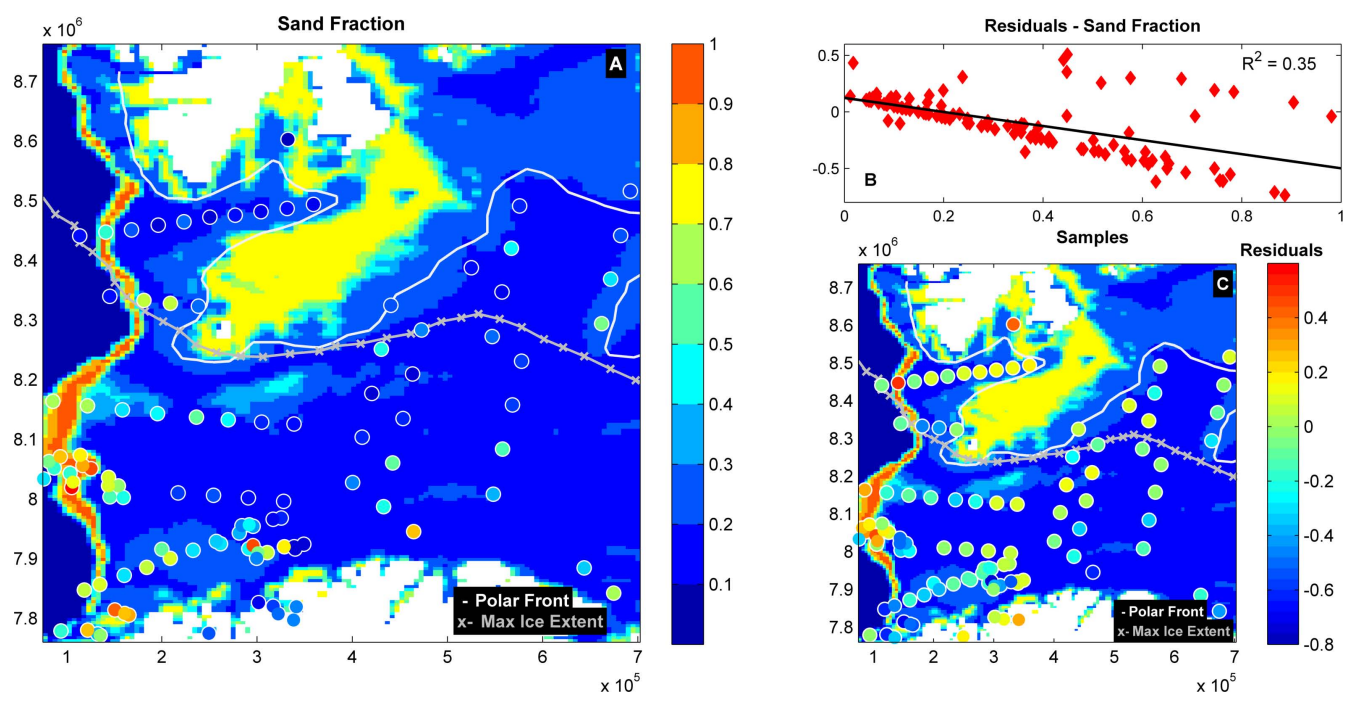

Fig. 5. (a) OF-Mod 3-D modelled sand fraction throughout the study region compared to data from the surface samples (circles). (b) Result of goodness-of-fit test on residuals (absolute difference model - samples). (c) Sand fraction residuals (circles) plotted on top of the OF-Mod 3-D results. The model reproduces the calibration data well.
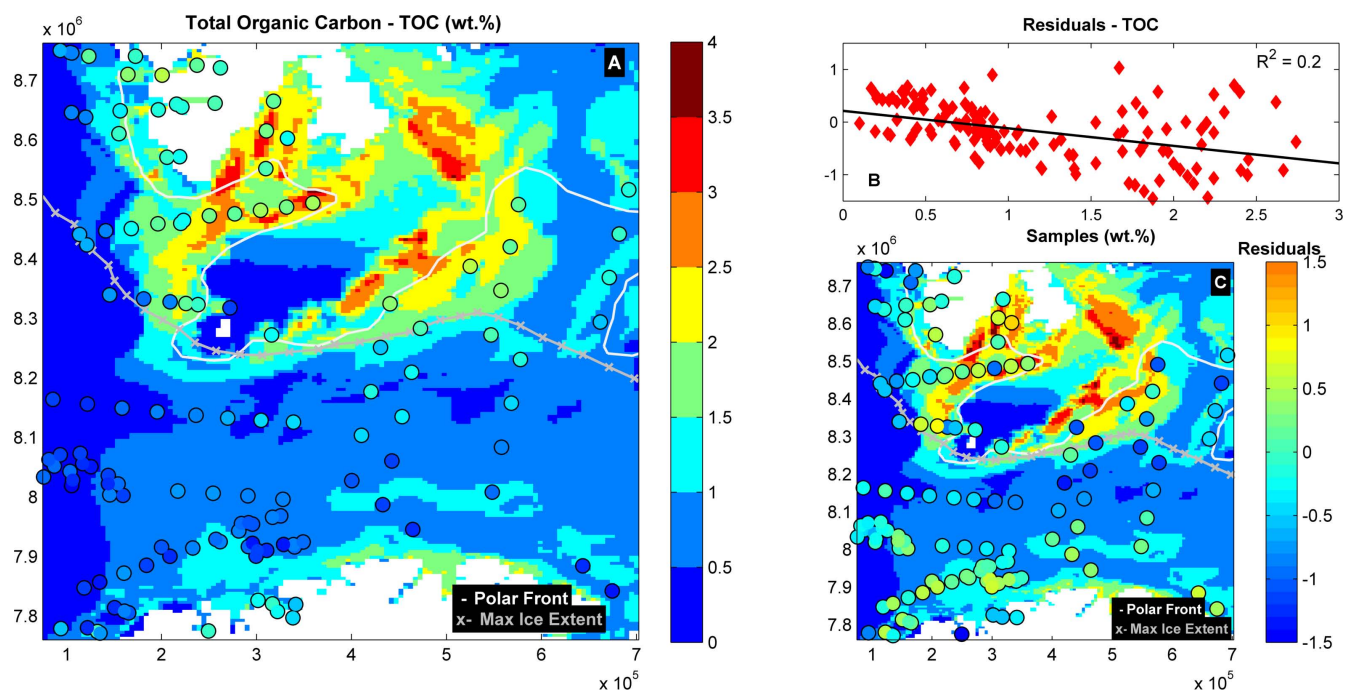

Fig. 6. (a) Modelled total organic carbon (TOC) compared to the calibration data set (circles). (b) Result of goodness-of-fit test on residuals (absolute difference model - samples). (c) TOC residuals (circles) plotted on top of the OF-Mod 3-D results. The OF-Mod 3-D results agree well with the observed data.

Primary productivity calculated from the core data reveals values of $80-110 \mathrm{gC} \mathrm{m}^{-2} \mathrm{yr}^{-1}$ within the $\mathrm{MIZ}$ and $<20 \mathrm{gC} \mathrm{m}^{-2} \mathrm{yr}^{-1}$ south of the MIZ. The model input productivity ranges from $30 \mathrm{gC} \mathrm{m}^{-2} \mathrm{yr}^{-1}$ south of the MIZ to $90 \mathrm{gC} \mathrm{m}^{-2} \mathrm{yr}^{-1}$ within the MIZ. The overall good consistency between measured and modelled MOC in the study area (Fig. 7) indicates possibly the more effective vertical export out of the photic zone within the MIZ rather than south of the MIZ. The mismatch between measured and modelled MOC data south of Spitsbergen Bank is likely due to the higher variability in primary productivity within the MIZ, which is not yet covered by the model input productivity ranges (Fig. 8). A possible solution would be a more dynamic distribution of primary productivity in Of-Mod, a tool that is currently under development.

Figure 9 shows the terrestrial organic carbon $\left(\mathrm{C}_{\text {terr }}\right)$ content of the sediment data compared to the model results. The distribution pattern of $\mathrm{C}_{\text {terr }}$ exhibits clear spatial trends with the highest values (up to $1.82 \mathrm{wt} . \%$ ) in the fjords and gradually lower values towards the ice-free, open-ocean environment in the southwestern Barents Sea. The lowermost values occur along the shelf break. The higher $C_{\text {terr }}$ values in sediments below seasonally ice-covered areas are explained by melting of sediment laden sea ice containing significant 


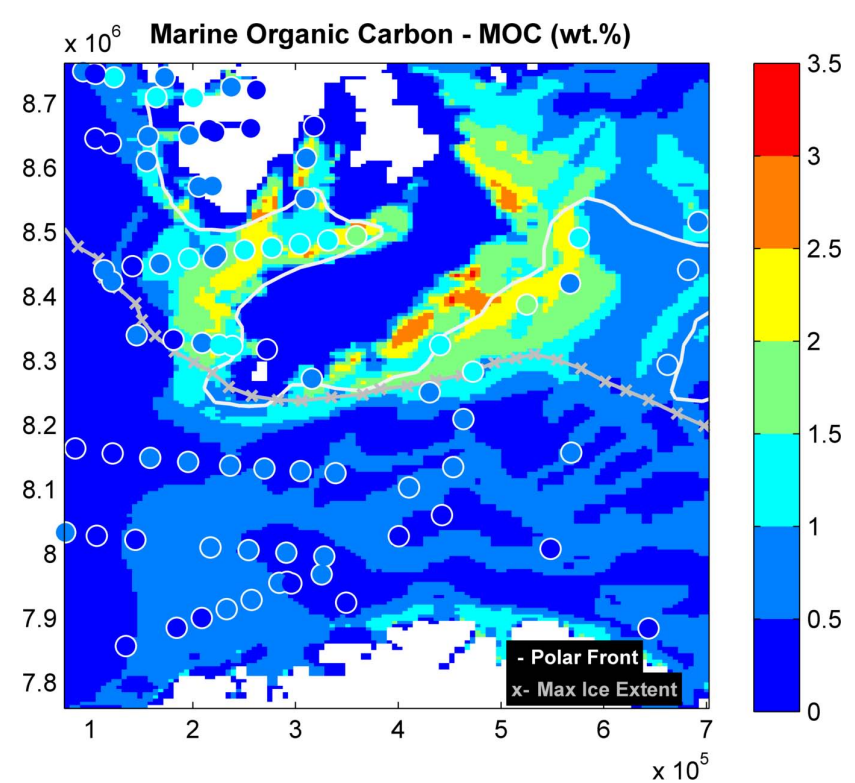

Fig. 7. Modelled marine organic carbon (MOC) compared to the calibration data set (circles). The model results agree well with the observed data. The general pattern of low MOC content in the southern part and high MOC content in the MIZ is well documented. The mismatch in areas south of Spitsbergen Bank is likely due to higher annual variability of the primary productivity distribution, which OF-Mod is currently not able to address completely.

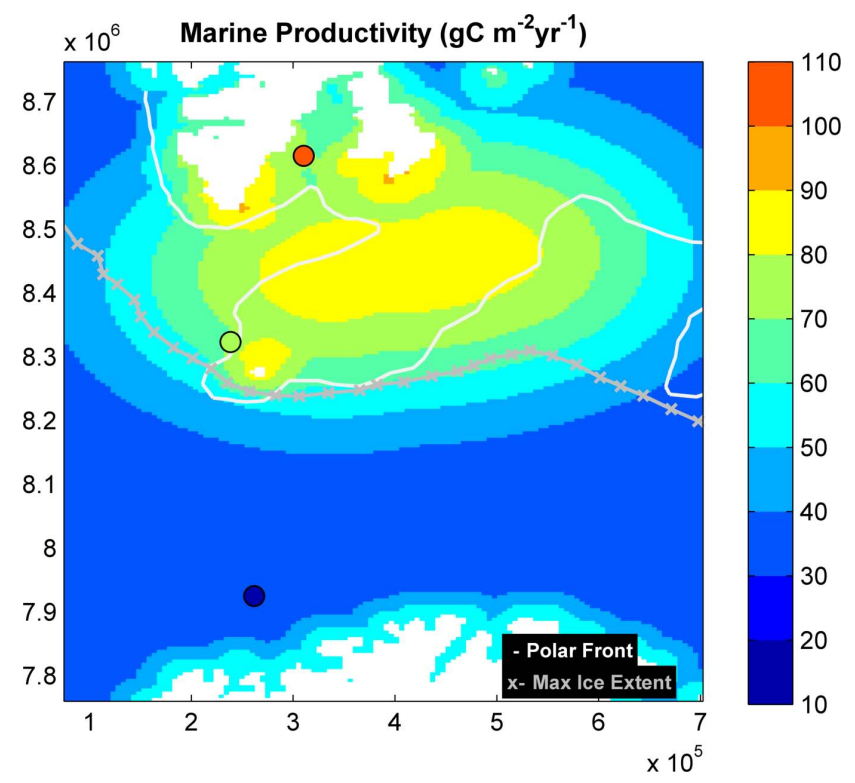

Fig. 8. Input primary productivity (PP) for OF-Mod 3-D compared to $\mathrm{PP}$ reconstructions from sediment cores (circles). The core data show a similar north-south trend as the model PP.

amounts of inorganic and terrigenous organic matter (Nürnberg et al., 1994; Reimnitz et al., 1994; Stein et al., 1994; Pfirman et al., 1997). Indeed, observations from sediment traps suggest that the release of terrestrial organic matter

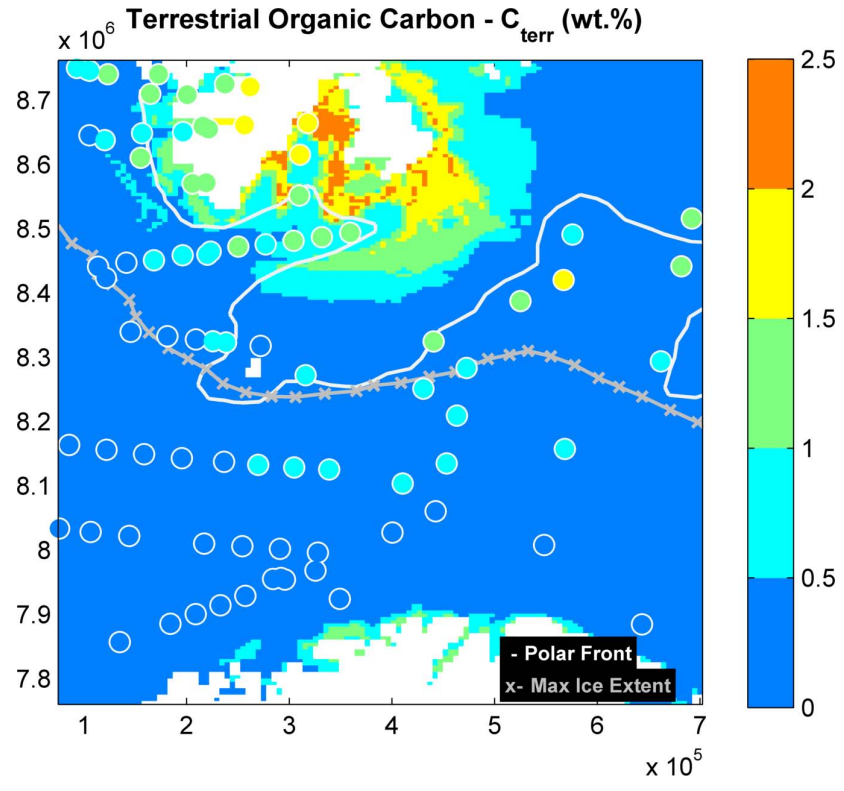

Fig. 9. Modelled total terrestrial organic carbon $\left(\mathrm{C}_{\text {terr }}\right)$ compared to the calibration data set (circles). The model results agree well with the observed data.

from melting sea ice in the Barents Sea provides significant contributions to the vertical export of organic matter (Andreassen et al., 1996; Wassmann et al., 2004). This picture is consistent with other Arctic shelf regions such as the Laptev and Kara seas (Stein and Macdonald, 2004c) and reflects the significance of terrigenous components for the organic carbon cycle in the Arctic Ocean. The pronounced gradient from the shore to the open ocean is attributed to glacio-fluvial and riverine transport of eroded sediments enriched in terrestrial organic matter from a densely vegetated drainage area off Spitsbergen (e.g. Knies et al., 2007). The distribution of $\mathrm{C}_{\text {terr }}$ in the study area is apparently independent of water depth, re-mineralisation processes and various sedimentation rates. Having already experienced some degradation and microbial attack in soils and during transport processes before entering the marine system, the terrestrial organic matter might be resistant to further extensive degradation at sea (Hedges and Keil, 1995).

The OF-Mod results for $\mathrm{C}_{\text {terr }}$ distribution are lower than the sedimentary data in general, but still of the same order of magnitude (0-2.5 wt.\%). The general pattern of low $\mathrm{C}_{\text {terr }}$ in the southern part and higher $\mathrm{C}_{\text {terr }}$ in the north with maximal values in the fjords of Svalbard is, however, captured sufficiently well, as is the distribution in Bear Island Trough. OFMod also predicts some $\mathrm{C}_{\text {terr }}$ accumulation on the NE flank of Spitsbergen Bank. The higher $\mathrm{C}_{\text {terr }}$ content in the samples upslope of Bear Island Trough and Hopen Deep is not reproduced. In addition to supply and the mixing model, terrestrial organic matter distribution in OF-Mod 3-D also depends on the distribution of the sand fraction of the sediment - with higher $\mathrm{SF}$ linked to higher $\mathrm{C}_{\text {terr }}$ (up to a maximum $\mathrm{SF}$ value, 


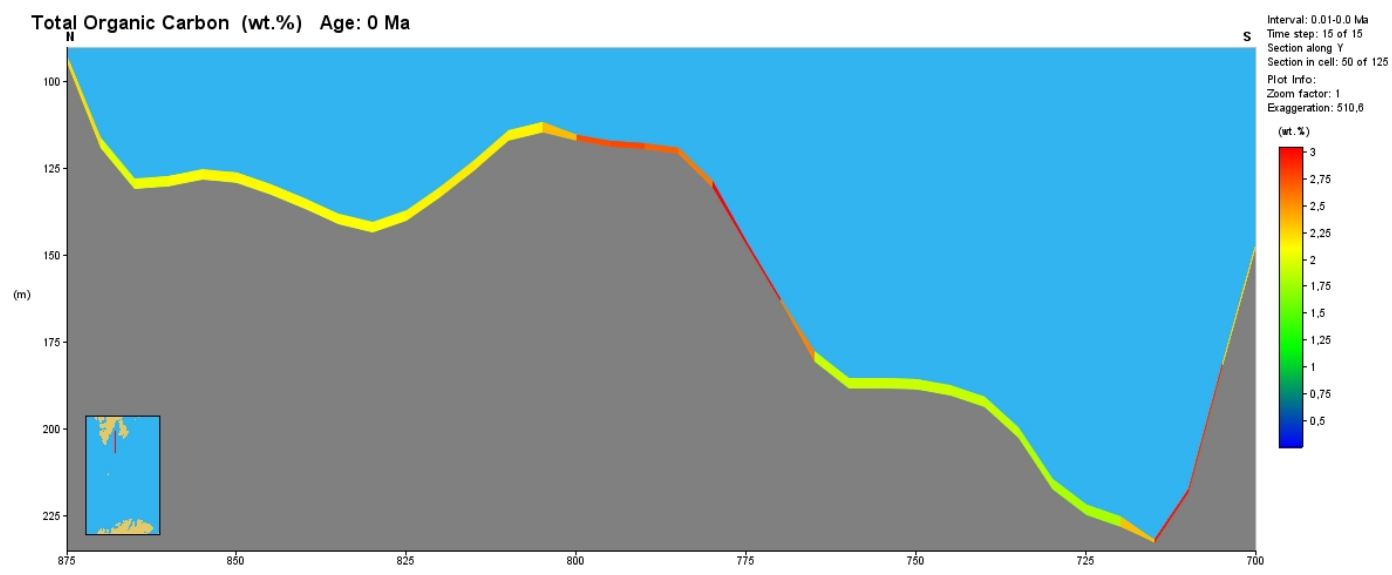

Fig. 10. OF-Mod 3-D profile of total organic carbon (TOC) through time (10 kyr, indicated as 0.01-0.0 Ma) in Storfjorden showing the lack of temporal variations in TOC deposition. The horizontal variations are captured by the corresponding TOC maps.

set here to 0.75). Lower modelled SF (see Sect. 4.2.1) thus also results in lower modelled $\mathrm{C}_{\text {terr }}$. Additionally, the mixing model in OF-Mod is threefold and allocates TOC to the marine, terrestrial and residual fractions, in contrast to the twoendmember approach used on the sedimentary data. Some mismatch between MOC modelled by OF-Mod and MOC calculated for the sediments, and similarly for $\mathrm{C}_{\text {terr }}$ from $\mathrm{OF}$ Mod and $\mathrm{C}_{\text {terr }}$ for the sediments, is expected because part of the total organic matter content in the sediments is in the residual fraction. The $\mathrm{C}_{\text {terr }}$ model results indicate that part of the terrestrial fraction in the model region indeed lies in the residual fraction.

\subsection{Organic carbon budget of the western Barents Sea}

The full 3-D model simulates organic carbon deposition throughout the Holocene - in the model defined as the last $10000 \mathrm{yr}$. With the current set-up, the modelled temporal changes are minimal (e.g. only $\pm 0.005 \mathrm{wt} \%$ TOC, \pm 0.0015 wt. \% MOC). Figure 10 shows a profile of TOC deposited in Storfjorden over the modelled time period as an example. There are no vertical, i.e. temporal, changes in organic carbon content. This implies stable depositional conditions in Storfjorden since the last deglaciation. The horizontal, i.e. spatial, variations are the only changes and are reflected in the maps discussed in the previous section.

Using modelled sedimentation rates (LSR) and dry bulk density (DBD), total sediment mass accumulation rates (MAR) in the study region can be derived via MAR $=$ LSR $\times$ DBD. Subsequently accumulation of organic matter (TOC, MOC, $\mathrm{C}_{\text {terr }}$ ) can be calculated by multiplying MAR with the respective quantity (whose units are wt.\% after all). The results are shown in Table 4 and Fig. 11. With the results from OF-Mod 3-D, accumulation rates and budgets can be calculated for each organic matter fraction and for each model grid cell. Regional variations in organic matter accumulation can be studied and hotspots of carbon ac- cumulation and regions of non-deposition can be identified. Additionally, using the position of the maximum ice extent, the study region is divided into a northern, ice-influenced part and a southern ice-free part, and separate budgets are calculated for these two areas. Total amounts of sediment and organic matter buried throughout the Holocene are recalculated for the last $11000 \mathrm{yr}$ in order to be able to compare the results to values calculated by Stein and Macdonald (2004b) for the Barents Sea and other Arctic Ocean shelf seas (Stein and Fahl, 2000; Stein and Macdonald, 2004c; Kuzyk et al., 2009; Kivimäe et al., 2010).

Total bulk sediment accumulation is maximal in the depressions like Storfjorden and Bear Island Trough, and north of Norway. In total $35.4 \times 10^{6} \mathrm{t}$ of sediment accumulate per year, corresponding to a total sediment input of $390 \times 10^{9} \mathrm{t}$ throughout the last $11000 \mathrm{yr}$. In comparison, Stein and Macdonald (2004b) provided estimates for bulk sediment accumulation for the whole Barents Sea (which has a total area of $1597 \times 10^{3} \mathrm{~km}^{2}$ ) based on Vetrov and Romankevich (2004), however leaving out the southwestern Barents Sea shelf edge. These rates (listed in Table 4) are approximately 7 times higher than our estimates for an area 3 times larger than our study region. The eastern Barents Sea includes deeper depressions and thicker sediment packages than the western part of the shelf (Gataullin et al., 1993; Gurevich, 1995; Polyak et al., 1995) that account for higher accumulation in comparison.

This study predicts the highest accumulation rates of total organic carbon (TOC) in Storfjorden $\left(>500 \mathrm{mgC} \mathrm{cm}^{-2} \mathrm{kyr}^{-1}\right.$ ), whereas there is almost no accumulation on Spitsbergen Bank (Fig. 11a). This results in $>120 \mathrm{tC} \mathrm{yr}^{-1}$ TOC buried in Storfjorden annually. Vetrov and Romankevich (2004) presented accumulation rates of total organic carbon for the Holocene in the central and eastern Barents Sea, leaving out the southwestern Barents Sea region and the western shelf edge. Their approach was based 
Table 4. Total sediment and organic carbon (total, terrestrial and marine) mass accumulation rates and total Holocene (11000 year) sediment and organic carbon burial in the study region compared to other Arctic Ocean shelf seas.

\begin{tabular}{|c|c|c|c|c|c|c|c|c|c|c|}
\hline \multirow[t]{2}{*}{ Region } & \multirow{2}{*}{$\begin{array}{r}\text { Size } \\
10^{3} \mathrm{~km}^{2}\end{array}$} & \multicolumn{2}{|c|}{ Total sediment } & \multicolumn{2}{|c|}{ Total organic carbon } & \multicolumn{2}{|c|}{ Terrestrial carbon } & \multicolumn{2}{|c|}{ Marine organic carbon } & \multirow[t]{2}{*}{ Reference } \\
\hline & & $10^{6} \mathrm{tyr}^{-1}$ & $10^{9} \mathrm{t}$ & $10^{6} \mathrm{tyr}^{-1}$ & $10^{9} \mathrm{t}$ & $10^{6} \mathrm{tyr}^{-1}$ & $10^{9} \mathrm{t}$ & $10^{6} \mathrm{tyr}^{-1}$ & $10^{9} \mathrm{t}$ & \\
\hline Barents Sea & 550 & 35.4 & 390 & 0.33 & 3.65 & 0.1 & 1.16 & 0.23 & 2.49 & This study \\
\hline Study region & & & & & & & & & & \\
\hline $\begin{array}{l}\text { Ice-covered } \\
\text { North }\end{array}$ & 262 & 16 & 176 & 0.19 & 2.13 & 0.06 & 0.65 & 0.14 & 1.49 & This study \\
\hline $\begin{array}{l}\text { Ice-free } \\
\text { South }\end{array}$ & 288 & 19.4 & 213 & 0.14 & 1.52 & 0.05 & 0.52 & 0.09 & 1 & This study \\
\hline $\begin{array}{l}\text { SW Shelf } \\
\text { Edge }\end{array}$ & 103 & 3 & 33.5 & 0.022 & 0.24 & 0.007 & 0.07 & 0.015 & 0.16 & This study \\
\hline $\begin{array}{l}\text { Total } \\
\text { Barents Sea }\end{array}$ & 1700 & 262 & 2882.5 & 2.8022 & 31.04 & 0.847 & 9.27 & 1.975 & 21.76 & $\begin{array}{r}\text { This study }+ \\
\text { Stein and Macdonald (2004) }\end{array}$ \\
\hline Barents Sea & 1597 & 259 & 2849 & 2.8 & 30.4 & 0.84 & 9.2 & 1.96 & 21.6 & Stein and Macdonald (2004) \\
\hline Laptev Sea & 498 & 67 & 737 & 0.98 & 10.8 & 0.9 & 9.9 & 0.08 & 0.9 & Stein and Macdonald (2004) \\
\hline Chukchi Sea & 620 & 19 & 209 & 0.23 & 2.5 & 0.11 & 1.2 & 0.12 & 1.3 & Stein and Macdonald (2004) \\
\hline Hudson Bay & 125 & 138 & & 1.27 & & 0.23 & & 1.03 & & Kuzyk et al. (2009) \\
\hline $\begin{array}{l}\text { Barents Sea } \\
\text { (last } 150 \mathrm{yr} \text { ) }\end{array}$ & 1512 & & & 9.2 & & & & & & Kivimäe et al. (2010) \\
\hline
\end{tabular}

on a large sediment sample data set and mapping was done taking into account topography, grain size, and hydrology but excluding links to organic matter supply. They used the sediment thickness map by Gurevich (1995) and sedimentation rates based on that map and on seismic data. The model in this study is based on the same sediment thickness map with the addition of the southwestern Barents region (see Sects. 3.4 and 4.1). In comparison, this study's TOC mass accumulation rate map has more detail and extends the Vetrov and Romankevich map in the western area towards the shelf edge. The overlapping regions of this study and Vetrov and Romankevich (2004) are in good agreement with this study predicting slightly higher organic carbon accumulation rates in Storfjorden (here $>500 \mathrm{mgC} \mathrm{cm}^{-2} \mathrm{kyr}^{-1}$ compared to $200-500 \mathrm{mgC} \mathrm{cm}^{-2} \mathrm{kyr}^{-1}$ ) and in Hopen Deep (here $200-300 \mathrm{mgC} \mathrm{cm}^{-2} \mathrm{kyr}^{-1}$ compared to $50-$ $200 \mathrm{mgC} \mathrm{cm}^{-2} \mathrm{kyr}^{-1}$ ). Both approaches predict negligible organic carbon accumulation on Spitsbergen Bank. The total annual accumulation of organic carbon based on this study is $0.33 \mathrm{tC} \mathrm{yr}^{-1}$ yielding approximately $3.65 \times 10^{9} \mathrm{tC}$ buried throughout the last 11000 yr. Compared to Stein and Macdonald (2004b), based on Vetrov and Romankevich (2004), these rates account for approximately $10 \%$ of the whole Barents Sea region (see Table 4).

The largest accumulation of marine organic carbon (MOC, Fig. 11b) also occurs in Storfjorden ( $>300 \mathrm{mgC} \mathrm{cm}^{-2} \mathrm{kyr}^{-1}$, corresponding to a burial flux of $60-90 \mathrm{tC} \mathrm{yr}^{-1}$ ) and in the northeastern part of the study region (Hopen Deep, 200$250 \mathrm{mgC} \mathrm{cm}^{-2} \mathrm{kyr}^{-1}$, corresponding to $60 \mathrm{tC} \mathrm{yr}^{-1}$ of MOC buried annually). These high values are likely due to the proximity of the ice and phytoplankton bloom influenced northern MIZ regions and the associated high flux of particulate organic matter towards the sea floor. Alternatively, resuspension of accumulated sediments elsewhere in the Bar- ents Sea and transport with bottom currents towards deeper glacial troughs are also common in the western Barents Sea (Sternberg et al., 2001; Thomsen et al., 2001; Sarnthein et al., 2003). However, high MOC accumulation rates are typically recorded in the troughs north of the MIZ, while values in the Bear Island trough south of the MIZ are relatively low (Fig. 11b). This likely excludes sediment resuspension as a prevailing factor for the high MOC accumulation rates in Storfjorden and Hopen Deep. Overall MOC accumulation is estimated at $0.23 \times 10^{6} \mathrm{tC} \mathrm{yr}^{-1}$, yielding a total of $2.49 \times 10^{9} \mathrm{tC}$ buried throughout the Holocene. These numbers also represent ca. $10 \%$ of the total MOC accumulation calculated by Stein and Macdonald (2004b) (Table 4). MOC accumulation is nearly absent on Spitsbergen Bank.

Spitsbergen Bank lies in the middle of the MIZ and primary productivity models show that marine primary production in the waters above Spitsbergen Bank is high (Wassmann et al., 2006b; Węsławski et al., 2012). Węsławski et al. (2012) postulate that Spitsbergen Bank may be a significant sink for marine organic carbon and a source of regenerated nutrients through recirculation and pumping of water through the coarse substrate. Our model shows some accumulation of marine organic matter on the southern flank of the bank, but according to our modelling results, overall, Spitsbergen Bank is not a significant sink for organic material.

With the exception of coastal Storfjorden, $\mathrm{C}_{\text {terr }}$ accumulation in the western Barents Sea is very low $\left(<100 \mathrm{mgC} \mathrm{cm}^{-2} \mathrm{kyr}^{-1}\right.$ on average, Fig. 11c), corresponding to an overall burial rate of $0.1 \times 10^{6} \mathrm{tC} \mathrm{yr}^{-1}$ and a total of $1.16 \times 10^{9} \mathrm{tC}$ buried throughout the last $11000 \mathrm{yr}$. The highest values of $C_{\text {terr }}$ accumulation occur in Storfjorden.

The western Barents shelf edge region missing in Vetrov and Romankevich (2004) and Stein and Macdonald (2004b) is included in this study and indicated in Fig. 3. The total 

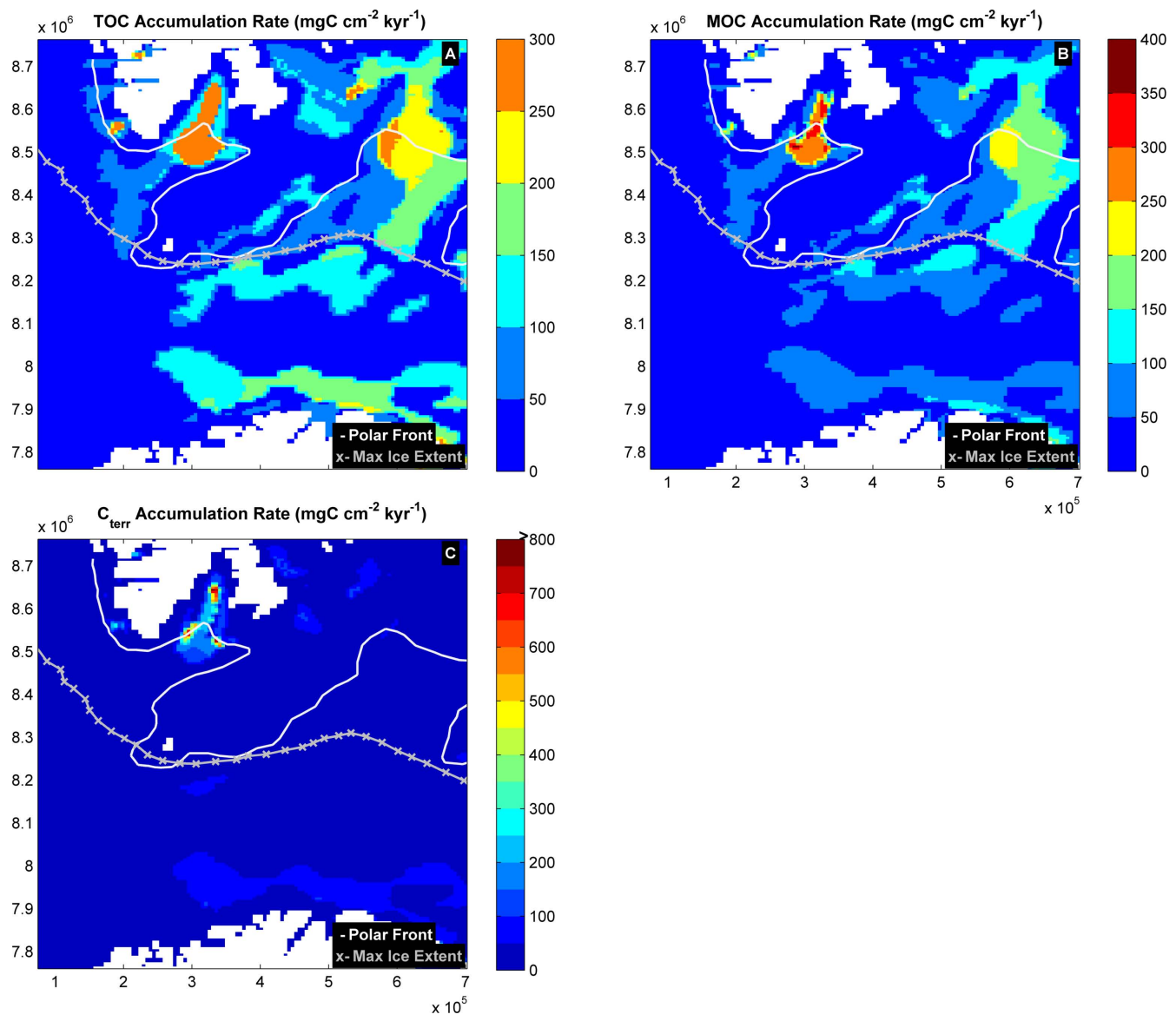

Fig. 11. Modelled (a) total (TOC) (b) marine (MOC) and (c) terrestrial $\left(\mathrm{C}_{\mathrm{terr}}\right)$ organic carbon mass accumulation rates (in mgC $\mathrm{cm}^{-2} \mathrm{kyr}^{-1}$ ) in the study region. The highest accumulation rates of TOC and MOC are calculated for Storfjorden, whereas there is almost no accumulation on Spitsbergen Bank. MOC accumulation rates are also high in Hopen Deep. In contrast, $\mathrm{C}_{\text {terr }}$ accumulation rates throughout in the western Barents Sea are very low.

area of this region is $10^{3} \times 10^{3} \mathrm{~km}^{2}$. The region lies in the southern Atlantic water influenced Barents Sea and receives ca. $3.0 \times 10^{6} \mathrm{t}$ of bulk sediment per year (Table 4). However, the burial flux of organic matter in this region is low $\left(0.022 \times 10^{6} \mathrm{tC} \mathrm{yr}^{-1}\right.$ for TOC, $0.015 \times 10^{6} \mathrm{tC} \mathrm{yr}^{-1}$ for MOC and $0.007 \times 10^{6} \mathrm{tC} \mathrm{yr}^{-1}$ for $\left.\mathrm{C}_{\mathrm{terr}}\right)$. Adding the results for the SW shelf edge to the total Barents Sea budget by Stein and Macdonald (2004b) (Table 4) provides a refinement of the Barents Sea carbon budget by including all relevant areas of the entire Barents Sea while only slightly increasing the overall budget.

Compared to other Arctic Ocean shelf seas (Table 4), the Laptev and Chukchi seas have similar areal extents as the western Barents shelf in this study. The western Barents shelf receives less sediment (ca. half) than the Laptev Sea and less OC (ca. one third) is buried annually. However, on the western Barents shelf ca. 3 times more MOC is buried annually (Stein and Macdonald, 2004b). Compared to the Chukchi Sea, the western Barents shelf receives ca. 2 times more sediment and similar amounts of $\mathrm{C}_{\text {terr }}$ are buried an- nually, whereas the Barents shelf receives more TOC and more MOC is buried here (Stein and Macdonald, 2004b). The total area of Hudson Bay is $841000 \mathrm{~km}^{2}$, whereas only $125000 \mathrm{~km}^{2}$ receives active sedimentation (Kuzyk et al., 2009). The smaller area, however, receives 3 times more sediment than the western Barents shelf and more TOC and MOC is buried in Hudson Bay (Kuzyk et al., 2009). Kivimäe et al. (2010) give an estimate of modern (last $150 \mathrm{yr}$ ) organic carbon accumulation in the whole Barents Sea region of $9.2 \times 10^{6} \mathrm{tC} \mathrm{yr}^{-1}$ based on Carroll et al. (2008). This work is based on ${ }^{210} \mathrm{~Pb}$ sedimentation rates in the Hopen Deep area, where our model also predicts higher organic carbon accumulation, especially MOC. However, $9.2 \times 10^{6} \mathrm{tC} \mathrm{yr}^{-1}$ is a much higher value than any of the Holocene age studies of the Arctic Ocean shelf seas predict.

Comparing the southern, permanently ice-free region (the area south of the maximum ice extent) to the seasonally ice-covered and ice-edge bloom influenced region (north of the maximum ice extent) yields the following results (Table 4). Accumulation of organic carbon in the ice-free 
southern region is low $\left(<80 \mathrm{tC} \mathrm{yr}^{-1} \mathrm{TOC},<40 \mathrm{tC} \mathrm{yr}^{-1}\right.$ MOC, $<40 \mathrm{tC} \mathrm{yr}^{-1} \mathrm{C}_{\text {terr }}$ compared to $80->180 \mathrm{tC} \mathrm{yr}^{-1}$ TOC, 40-90 tC yr${ }^{-1} \mathrm{MOC},>40 \mathrm{tC} \mathrm{yr}^{-1} \mathrm{C}_{\text {terr }}$ in the north). More organic matter is buried annually in the seasonally ice-covered northern region. In total there is more bulk sediment accumulated annually south of the maximum ice extent $\left(19.4 \times 10^{6} \mathrm{tC} \mathrm{yr}^{-1}\right)$ in a slightly larger area $\left(288 \times 10^{3} \mathrm{~km}^{2}\right.$ versus $\left.262 \times 10^{3} \mathrm{~km}^{2}\right)$ than in the north $\left(16 \times 10^{6} \mathrm{tC} \mathrm{yr}^{-1}\right)$, but less organic material stored in the south $\left(0.14 \times 10^{6} \mathrm{tC} \mathrm{yr}^{-1}\right.$ compared to $0.19 \times 10^{6} \mathrm{tC} \mathrm{yr}^{-1}$ in the north). This difference between ice-free and ice-covered regions suggests that changes in the ice cover will result in changes in the OC storage across the area. If all other conditions stay the same, then decreasing ice cover will likely lead to reduced storage of OC on the western Barents Sea shelf.

This TOC distribution reflects our modelled primary productivity (Fig. 8). The higher PP in the north also results in higher storage even though there is no accumulation on Spitsbergen Bank. However, our modelled PP differs from ocean-ecosystem primary productivity models (Ellingsen et al., 2008; Wassmann et al., 2010). These models predict highest PP in the southern, Atlantic water influenced region, higher production on top of Spitsbergen Bank and overall low PP in the northern, Arctic water influenced region. Their predicted PP values are also higher than our reconstructed PP: $>100 \mathrm{gC} \mathrm{m}^{-2} \mathrm{yr}^{-1}$ predicted in the south compared to $<50 \mathrm{gC} \mathrm{m}^{-2} \mathrm{yr}^{-1}$ reconstructed; $<100 \mathrm{gC} \mathrm{m}^{-2} \mathrm{yr}^{-1}$ predicted in the north compared to up to $90 \mathrm{gC} \mathrm{m}^{-2} \mathrm{yr}^{-1}$ reconstructed. These differences can in part be attributed to the different modelling approaches - 3-D ocean models taking currents and circulation, i.e. water column processes into account compared to the sedimentary approach backcalculating from the material that was actually deposited, and averaging over different time intervals (monthly/seasonal versus averaging over 100s-1000s of years in the sedimentary model). However, more fundamental questions relating PP in the euphotic zone of the surface ocean to PP reconstructed from sedimentary organic carbon remain. A central question is how the processes in the water column are translated into the sedimentary model. Reconstructed PP presented here is a reflection of the bottom-up approach for back-calculating necessary input of organic matter from the material that was actually deposited. Organic carbon content of the sediments and primary productivity in the surface waters are linked by vertical export of organic matter out of the photic zone (see Sects. 3, 4) (Felix, 2014). This is taken into account in OF-Mod 3-D (see Eq. 1). However, the western Barents shelf is relatively shallow on average $(200 \mathrm{~m})$ and the links to vertical export out of the photic zone may be stronger than currently implemented in OF-Mod 3-D. Vertical carbon fluxes are highly variable (Olli et al., 2002; Reigstad et al., 2008, 2011) and pelagic-benthic coupling in the region is strong (Wassmann et al., 2006a). The higher organic carbon content of the northern, ArW and ice-influenced region could be a reflection of a highly variable primary production regime with efficient vertical export and less recycling of nutrients in the water column than in the southern Barents Sea and more efficient burial than currently implemented. This is under further investigation and being prepared in a follow-up manuscript.

On the other hand, modelling of PP in a future, ice-free scenario with higher air and sea surface temperatures in the Barents Sea as compared to today suggests an increase in PP in the northern, Arctic water domain opposed to a decrease in production in the southern, Atlantic water domain (Ellingsen et al., 2008; Slagstad et al., 2011). This PP distribution pattern seems at first glance similar to our Holocene-average PP distribution. Since our sedimentary model averages over considerably longer time spans than ocean-ecosystem models (thousands of years compared to monthly/seasonal) and covers the last $10000 \mathrm{yr}$, our PP distribution could be reflecting an overall warmer scenario. On the whole the Holocene in the Barents Sea region has been warmer than today, with the mid-Holocene thermal maximum and a cooling trend with a decrease in sea surface temperatures and an increase in sea ice cover in the last $5000 \mathrm{yr}$ BP until the start of the industrial period (Sarnthein et al., 2003; Renssen et al., 2005; Wanner et al., 2008; Risebrobakken et al., 2010).

\section{Conclusions}

This study shows that OF-Mod 3-D is a valuable tool for regional modelling of the distribution of the marine and terrestrial organic carbon fractions and for reconstructing primary productivity beyond core control on (sub-)recent timescales. The model is calibrated and the model results represent the surface sediment data well. Modelled sedimentation rates agree with published data and modelled lithology closely reflects the sediment data. Modelled total organic carbon content reproduces the calibration data well and captures the higher carbon content in the MIZ region and low carbon content in the southern part of the study region.

The marine and terrestrial organic carbon fractions determined from sediment samples are separated by a new approach using $\delta^{13} \mathrm{C}_{\text {org }}$ and the percentage of organic nitrogen contained in the samples $\left(\% \mathrm{~N}_{\text {org }}\right)$ in the mixing model. The model predicts the highest marine organic carbon content of the sediments along the southern flank of Spitsbergen Bank. The distribution of the organic carbon fractions is consistent with the presence of a spatially variable mixture of autochthonous and allochthonous sources of organic matter and support observations of various shelf areas in the Arctic Ocean (Stein and Macdonald, 2004c).

Reconstructed primary productivity is highest in the MIZ region and low throughout the southwestern Barents Sea. This observation is contrary to results derived from the physical-biological coupled model (SINMOD) (Slagstad et al., 2011) and may in part be attributed to the different modelling approaches. Accumulation of organic carbon in the 
ice-free southern region is lower than in the seasonally icecovered northern region, implying that shrinking sea ice may reveal a negative effect on the overall organic carbon storage capacity of the western Barents Sea shelf. In total there is more bulk sediment accumulated annually south of the maximum ice extent but less organic material. Adding the results for the SW shelf edge to the total Barents Sea budget by Stein and Macdonald (2004b) provides a refinement of the Barents Sea carbon budget by including all relevant areas of the entire Barents Sea while only slightly increasing the overall budget.

Acknowledgements. This research is funded under the European Community's 7th Framework Programme FP7 2007/2013, MarieCurie Actions, under Grant Agreement No. 238111 - CASE ITN and partly supported by the Research Council of Norway through its Centres of Excellence funding scheme, Grant Agreement No. 223259/F5. The authors also wish to thank the MAREANO program (www.mareano.no) for allowing the generous use of sediment and core data for this project. All MAREANO partners and cruise participants are thanked for their contributions.

Edited by: H. Renssen

\section{References}

Andreassen, I., Nöthig, E.-M., and Wassmann, P.: Vertical particle flux on the shelf off northern Spitsbergen, Norway, Mar. Ecol. Progr. Ser., 137, 215-228, 1996.

Arrigo, K. R., Perovich, D. K., Pickart, R. S., Brown, Z. W., van Dijken, G. L., Lowry, K. E., Mills, M. M., Palmer, M. A., Balch, W. M., Bahr, F., Bates, N. R., Benitez-Nelson, C., Bowler, B., Brownlee, E., Ehn, J. K., Frey, K. E., Garley, R., Laney, S. R., Lubelczyk, L., Mathis, J., Matsuoka, A., Mitchell, B. G., Moore, G. W. K., Ortega-Retuerta, E., Pal, S., Polashenski, C. M., Reynolds, R. A., Schieber, B., Sosik, H. M., Stephens, M., and Swift, J. H.: Massive Phytoplankton Blooms Under Arctic Sea Ice, Science, 336, p. 1408, doi:10.1126/science.1215065, 2012.

Bellec, V. K., Bøe, R., Rise, L., Slagstad, D., Longva, O., and Dolan, M. F. J.: Rippled scour depressions on continental shelf bank slopes off Nordland and Troms, Northern Norway, Continental Shelf Res., 30, 1056-1069, doi:10.1016/j.csr.2010.02.006, 2010.

Bergamaschi, B. A., Tsamakis, E., Keil, R. G., Eglinton, T. I., Montlucon, D. B., and Hedges, J. I.: The effect of grain size and surface area on organic matter, lignin and carbohydrate concentration, and molecular composition in Peru Margin sediments, Geochim. Cosmochim. Acta, 61, 1247-1260, 1997.

Betts, J. N. and Holland, H. D.: The oxygen content of ocean bottom waters, the burial efficiency of organic carbon, and the regulation of atmospheric oxygen, Palaeogeogr. Palaeocli. Palaeoecol., 97, 5-18, 1991.

Betzer, P. R., Showers, W. J., Laws, E. A., Winn, C. D., di Tullio, G. R., and Kroopnick, P. M.: Primary productivity and particle fluxies on a transect to the equator ant $153 \mathrm{~W}$ in the Pacific Ocean, Deep-Sea Res., 31, 1-11, 1984.
Boitsov, S., Jensen, H. K. B., and Klungsøyr, J.: Natural background and anthropogenic inputs of polycyclic aromatic hydrocarbons (PAH) in sediments of South-Western Barents Sea, Mar. Environ. Res., 68, 236-245, 2009.

Brown, T., Belt, S., Philippe, B., Mundy, C., Massé, G., Poulin, M., and Gosselin, M.: Temporal and vertical variations of lipid biomarkers during a bottom ice diatom bloom in the Canadian Beaufort Sea: further evidence for the use of the IP25 biomarker as a proxy for spring Arctic sea ice, Polar Biol., 34, 1857-1868, doi:10.1007/s00300-010-0942-5, 2011.

Bøe, R., Bellec, V. K., Dolan, M. F. J., Buhl-Mortensen, P., BuhlMortensen, L., Slagstad, D., and Rise, L.: Giant sandwaves in the Hola glacial trough off Vesterålen, North Norway, Mar. Geol., 267, 36-54, 2009.

Carroll, J., Zaborska, A., Papucci, C., Schirone, A., Carroll, M. L., and Pempkowiak, J.: Accumulation of organic carbon in western Barents Sea sediments, Deep Sea Res. II, 55, 2361-2371, doi:10.1016/j.dsr2.2008.05.005, 2008.

Crusius, J. and Kenna, T. C.: Ensuring confidence in radionuclidebased sediment chronologies and bioturbation rates, Estuarine, Coast. Shelf Sci.e, 71, 537-544, doi:10.1016/j.ecss.2006.09.006, 2007.

Demicco, R. V. and Klir, G. J.: Fuzzy Logic in Geology, Elsevier, 374 pp., 2004.

Ellingsen, I., Dalpadado, P., Slagstad, D., and Loeng, H.: Impact of climatic change on the biological production in the Barents Sea, Clim. Change, 87, 155-175, doi:10.1007/s10584-007-93696, 2008.

Elverhøi, A. and Solheim, A.: The Barents Sea ice sheet - a sedimentological discussion, Polar Res., 1, 23-42, 1983.

Elverhøi, A.: Glacigenic and associated marine sediments in the Weddell Sea, fjords of Spitsbergen and the Barents Sea, Mar. Geol., 57, 53-88, 1984.

Elverhøi, A., Pfirman, S. L., Solheim, A., and Larssen, B. B.: Glaciomarine sedimentation in epicontinental seas exemplified by the northern Barents Sea, Mar. Geol., 85, 225-250, doi:10.1016/0025-3227(89)90155-2, 1989.

Faleide, J. I., Vågnes, E., and Gudlaugsson, S. T.: Late MesozoicCenozoic evolution of the south-western Barents Sea in a regional rift-shear tectonic setting, Mar. Petrol. Geol., 10, 186-214, 1993.

Felix, M.: A comparison of equations commonly used to calculate organic carbon content and marine palaeoproductivity from sediment data, Mar. Geol., 347, 1-11, 2014.

Felix, M., Majewska-Bill, M., Mann, U., and Rinna, J.: Faciesbased sedimentological modelling for use in simulation of organic carbon deposition and burial, AAPG Hedberg Conference 2012, Nice, France, 2012.

Gataullin, V., Polyak, L., Epstein, O., and Romanyuk, B.: Glacigenic deposits of the Central Deep: a key to the Late Quaternary evolution of the estern Barents Sea, Boreas, 22, 47-58, 1993.

Gurevich, V. I.: Recent sedimentogenesis and environment on the Arctic shelf of Western Eurasia, Oslo, 1-92, 1995.

Hedges, J. I. and Keil, R. G.: Sedimentary organic matter preservation: an assessment and speculative synthesis, Mar. Chem., 49, 81-115, 1995. 
Heldal, H. E., Varskog, P., and Føyn, L.: Distribution of selected anthropogenic radionuclides (137Cs, 238Pu, 239,240Pu and 241 Am) in marine sediments with emphasis on the Spitsbergen Bear Island area, Sci. Total Environ., 293, 233-245, 2002.

IPCC: Climate Change 2007: Synthesis Report. Contribution of Working Groups I, II and III to the Fourth Assessment Report of the Intergovernmental Panel on Climate Change, edited by: Core Writing Team, Pachauri, R. K., and Reisinger, A., IPCC, Geneva, Switzerland, 104, 2007.

Jakobsson, M., Macnab, R., Mayer, L., Anderson, R., Edwards, M., Hatzky, J., Schenke, H. W., and Johnson, P.: An improved bathymetric portrayal of the Arctic Ocean: Implications for ocean modeling and geological, geophysical and oceanographic analyses, Geophys. Res. Lett., 35, L07602, doi:10.1029/2008g1033520, 2008.

Jasper, J. P. and Gagosian, R. B.: The sources and deposition of organic matter in the Late Quaternary Pigmy Basin, Gulf of Mexico, Geochim. Cosmochim. Acta, 54, 1117-1132, 1990.

Jensen, H., Knies, J., Finne, T. E., and Thorsnes, T.: Mareano 2006 - miljøgeokjemiske resultater fra Tromsøflaket, Ingøy-djupet, Lopphavet og Sørøysundet Geological Survey of Norway, Trondheim, Norway, 270, 2007.

Jensen, H., Knies, J., Finne, T. E., and Thorsnes, T.: Mareano 2007 miljøgeokjemiske resultater fra Troms II og Troms III Geological Survey of Norway, Trondheim, Norway, 253, 2008.

Johannessen, S. C. and Macdonald, R. W.: There is no 1954 in that core! Interpreting sedimentation rates and contaminant trends in marine sediment cores, Mar. Pollut. Bull., 64, 675-678, doi:10.1016/j.marpolbul.2012.01.026, 2012.

Junttila, J., Aagaard-Sørensen, S., Husum, K., and Hald, M.: Late Glacial-Holocene clay minerals elucidating glacial history in the SW Barents Sea, Mar. Geol., 276, 71-85, doi:10.1016/j.margeo.2010.07.009, 2010.

Keil, R. G., Tsamakis, E., Giddings, J. C., and Hedges, J. I.: Biochemical distribution (amino acids, neutral sugars, and lignin phenols) among size-classes of modern marine sediments from the Washington coast, Geochim. Cosmochim. Acta, 62, 13471364, 1998.

Kivimäe, C., Bellerby, R. G. J., Fransson, A., Reigstad, M., and Johannessen, T.: A carbon budget for the Barents Sea, Deep Sea Res. I, 57, 1532-1542, doi:10.1016/j.dsr.2010.05.006, 2010.

Knies, J. and Mann, U.: Depositional environment and source rock potential of Miocene strata from the central Fram Strait: introduction of a new computing tool for simulating organic facies variations, Mar. Petrol. Geol., 19, 811-828, 2002.

Knies, J., Jensen, H., Finne, T. E., Lepland, A., and Saether, O. M.: Sediment composition and heavy metal distribution in Barents Sea surface samples: Results from Institute of Marine Research 2003 and 2004 cruises Geological Survey of Norway, Trondheim, Norway, 44, 2006.

Knies, J., Brookes, S., and Schubert, C. J.: Re-assessing the nitrogen signal in continental margin sediments: New insights from the high northern latitudes, Earth Planetary Sci. Lett., 253, 471-484, doi:10.1016/j.eps1.2006.11.008, 2007.

Knies, J. and Martinez, P.: Organic matter sedimentation in the western Barents Sea region: Terrestrial and marine contribution based on isotopic composition and organic nitrogen content, Nor. J. Geol., 89, 79-89, 2009.
Kuzyk, Z. Z. A., Macdonald, R. W., Johannessen, S. C., Gobeil, C., and Stern, G. A.: Towards a sediment and organic carbon budget for Hudson Bay, Mar. Geol., 264, 190-280, 2009.

Lebesbye, E.: Late Cenozoic Glacial History of the Southwestern Barents Sea, PhD, University of Troms $\emptyset$, Troms $\varnothing$, Norway, 177 pp., 2000.

Loeng, H.: Features of the physical oceanographic conditions of the Barents Sea, in: Proceedings of the Pro Mare Symposium on Polar Marine Ecology, Trondheim, 1991,

Maiti, K., Carroll, J., and Benitez-Nelsen, C. R.: Sedimentation and particle dynamics in the seasonal ice zone of the Barents Sea, J. Mar. Syst., 79, 185-198, 2010.

Mann, U. and Zweigel, J.: Modelling source-rock distribution an quality variations: the organic facies modelling approach, Spec. Publ. Int. Assoc. Sedimentol., 40, 239-274, 2008.

Mann, U., Knies, J., Chand, S., Jokat, W., Stein, R., and Zweigel, J.: Evaluation and modelling of Tertiary source rocks in the central Arctic Ocean, Mar. Petrol. Geol., 26, 1624-1639, doi:10.1016/j.marpetgeo.2009.01.008, 2009.

Navarro-Rodriguez, A., Belt, S. T., Knies, J., and Brown, T. A.: Mapping recent sea ice conditions in the Barents Sea using the proxy biomarker IP25: implications for palaeo sea ice reconstructions, Quaternary Sci. Rev., 79, 26-39, doi:10.1016/j.quascirev.2012.11.025, 2013.

Nürnberg, D., Wollenburg, I., Dethleff, D., Eicken, H., Kassens, H., Letzig, T., Reimnitz, E., and Thiede, J.: Sediments in the Arctic sea ice: Implications for entrainment, transport and release, Mar. Geol., 119, 185-214, 1994.

Olli, K., Wexels Riser, C., Wassmann, P., Ratkova, T., Arashkevich, E., and Pasternak, A.: Seasonal variation in vertical flux of biogenic matter in the marginal ice zone and the central Barents Sea, J. Mar. Syst., 38, 189-204, 2002.

Pfirman, S. L., Colony, R., Nürnberg, D., Eicken, H., and Rigor, I.: Reconstructing the origin and trajectory of drifting Arctic sea ice, J. Geophys. Res., 102, 12575-12586, 1997.

Polyak, B., Lehman, S. J., Gataullin, V., and Timothy Jull, A. J.: Two-step deglaciation of the southeastern Barents Sea, Geology, 23, 567, doi:10.1130/00917613(1995)023<0567:tsdots>2.3.co;2, 1995.

Rasmussen, T. L., Thomsen, E., Ślubowska, M. A., Jessen, S., Solheim, A., and Koç, N.: Paleoceanographic evolution of the SW Svalbard margin $\left(76^{\circ} \mathrm{N}\right)$ since $20,00014 \mathrm{C}$ yr BP, Quaternary Res., 67, 100-114, doi:10.1016/j.yqres.2006.07.002, 2007.

Reigstad, M., Wexels Riser, C., Wassmann, P., and Ratkova, T.: Vertical export of particulate organic carbon: Attenuation, composition and loss rates in the northern Barents Sea, Deep Sea Res. II, 55, 2308-2319, doi:10.1016/j.dsr2.2008.05.007, 2008.

Reigstad, M., Carroll, J., Slagstad, D., Ellingsen, I., and Wassmann, P.: Intra-regional comparison of productivity, carbon flux and ecosystem composition within the northern Barents Sea, Progr. Oceanogr., 90, 33-46, doi:10.1016/j.pocean.2011.02.005, 2011. 
Reimer, P. J., Baillie, M. G. L., Bard, E., Bayliss, A., Beck, J. W., Blackwell, P. G., Ramsey, C. B., Buck, C. E., Burr, G. S., Edwards, R. L., Friedrich, M., Grootes, P. M., Guilderson, T. P., Hajdas, I., Heaton, T. J., Hogg, A. G., Hughen, K. A., Kaiser, K. F., Kromer, B., McCormac, F. G., Manning, S. W., Reimer, R. W., Richards, D. A., Southon, J. R., Talamo, S., Turney, C. S. M., van der Plicht, J., and Weyhenmeyer, C. E.: IntCal09 and Marine09 radiocarbon age calibration curves, 0-50,000 years cal BP, Radiocarbon, 51, 1111-1150, 2009.

Reimnitz, E., Dethleff, D., and Nürnberg, D.: Contrasts in Arctic shelf sea-ice regimes and some implications: Beaufort Sea versus Laptev Sea, Mar. Geol., 119, 215-225, 1994.

Renssen, H., Goosse, H., Fichefet, T., Brovkin, V., Driesschaert, E., and Wolk, F.: Simulating the Holocene climate evolution at northern high latitiudes using a couple atmospheresea ice-ocean-vegetation model, Clim. Dynam., 24, 23-43, doi:10.1007/s00382-004-0485-y, 2005.

Risebrobakken, B., Moros, M., Ivanova, E. V., Chistyakova, N., and Rosenberg, R.: Climate and oceanographic variability in the SW Barents Sea during the Holocene, The Holocene, 20, 609-621, doi:10.1177/0959683609356586, 2010.

Rüther, D. C., Mattingsdal, R., Andreassen, K., Forwick, M., and Husum, K.: Seismic architecture and sedimentology of a major grounding zone system deposited by the Bjørnøyrenna Ice Stream during Late Weichselian deglaciation, Quaternary Sci. Rev., 30, 2776-2792, doi:10.1016/j.quascirev.2011.06.011, 2011

Sakshaug, E. and Skjoldal, H. R.: Life at the ice edge, Ambio, 18, 60-67, 1989.

Sakshaug, E. and Kovacs, K.: Introduction, in: Ecosystem Barents Sea, edited by: Sakshaug, E., Johnsen, G., and Kovacs, K., Tapir Academic Press, Trondheim, 9-32, 2009.

Sarnthein, M., Kreveld, S. V., Erlenkeuser, H., Grootes, P. M., Kucera, M., Pflaumann, U., and Schulz, M.: Centennial-tomillennial-scale periodicities of Holocene climate and sediment injections off the western Barents shelf, $75 \mathrm{~N}$, Boreas, 32, 447461, doi:10.1080/03009480310003351, 2003.

Schubert, C. J. and Calvert, S. E.: Nitrogen and carbon isotopic composition of marine and terrestrial organic matter in Arctic Ocean sediments: implications for nutrient utilization and organic matter composition, Deep Sea Res. I, 48, 789-810, 2001.

Schwartzkopf, T. A.: Model for prediciton of organic carbon content in possible source rocks, Mar.d Petrol. Geol., 10, 478-491, 1993.

Serreze, M. C., Holland, M. M., and Stroeve, J.: Perspectives on the Arctic's Shrinking Sea-Ice Cover, Science, 315, 1533-1536, doi:10.1126/science.1139426, 2007.

Silva, J. A. and Bremner, J. M.: Determination and IsotopeRatio Analysis of Different Forms of Nitrogen in Soils: 5. Fixed Ammonium1, Soil Sci. Soc. Am. J., 30, 587-594, doi:10.2136/sssaj1966.03615995003000050017x, 1966.

Slagstad, D., Downing, K., Carlotti, F., and Hirche, H.-J.: Modelling the carbon export and air-sea flux of CO2 in the Greenland Sea, Deep Sea Res. II, 46, 1511-1530, 1999.

Slagstad, D., Ellingsen, I. H., and Wassmann, P.: Evaluating primary and secondary production in an Arctic Ocean void of summer sea ice: An experimental simulation approach, Prog. Oceanogr., 90, 117-131, doi:10.1016/j.pocean.2011.02.009, 2011.
Soetaert, K., Herman, P. M. J., Middelburg, J. J., Heip, C., deStigter, H. S., van Weering, T. C. E., Epping, E., and Helder, W.: Modeling 210Pb-derived mixing activity in ocean margin sediments: Diffusive versus nonlocal mixing, J. Mar. Res., 54, 1207-1227, 1996.

Stein, R.: Accumulation of Organic Carbon in Marine Sediments, Lecture Notes in Earth Sciences, Springer, 217 pp., 1991.

Stein, R., Grobe, H., and Wahsner, M.: Organic carbon, carbonate, and clay mineral distributions in eastern central Arctic Ocean surface sediments, Mar. Geol., 119, 269-285, 1994.

Stein, R. and Fahl, K.: Holocene accumulation of organic carbon at the Laptev Sea continental margin (Arctic Ocean): sources, pathways, and sinks, Geo-Mar. Lett., 20, 27-36, 2000.

Stein, R. and Macdonald, R. W.: Geochemical Proxies used for Organic Carbon Source Identification in Arctic Ocean Sediments, in: The Organic Carbon Cycle in the Arctic Ocean, edited by: Stein, R. and Macdonald, R. W., Springer, 24-32, 2004a.

Stein, R. and Macdonald, R. W.: Organic Carbon Budget: Arctic Ocean vs. Global Ocean, in: The Organic Carbon Cycle in the Arctic Ocean, edited by: Stein, R. and Macdonald, R. W., Springer, 315-322, 2004b.

Stein, R. and Macdonald, R. W.: The Organic Carbon Cycle in the Arctic Ocean, Springer, 363 pp., 2004c.

Sternberg, R. W., Aagaard, K., Cacchione, D., Wheatcroft, R. A., Beach, R. A., Roach, A. T., and Marsden, M. A. H.: Long-term nearbed observations of velocity and hydrographic properties in the northeast Barents Sea with implications for sediment transport, Cont. Shelf Res., 21, 509-529, 2001.

Stuiver, M. and Reimer, P. J.: Extended 14C databse and revised CALIB radiocarbon calibration program, Radiocarbon, 35, 215 230, 1993.

Tamelander, T., Renaud, P. E., Hop, H., Carroll Jr., M. L., W. G. A., and Hobson, K. A.: Trophic relationships and pelagic-benthic coupling during summer in the Barents Sea Marginal Ice Zone, revealed by stable carbon and nitrogen isotope measurements, Mar. Ecol. Progr. Ser., 310, 33-46, doi:10.3354/meps310033, 2006.

Thomsen, C., Blaume, F., Formann, H., Peeken, I., and Zeller, U.: Particle transport procesesses at slope environments: event driven flux across the Barents Sea continental margin, Mar. Geol., 175, 237-250, 2001.

Tommerås, A. and Mann, U.: Improved Hydrocarbon Charge Prediction by Use of Source Rock Modelling, EAGE Research Workshop - From Seismic Interpretation to Stratigraphic and Basin Modelling - Present and Future Grenoble, France, 2006.

Vare, L. L., Masse, G., and Belt, S. T.: A biomarkerbased reconstruction of sea ice conditions for the Barents Sea in recent centuries, The Holocene, 20, 637-643, doi:10.1177/0959683609355179, 2010.

Vetrov, A. and Romankevich, E.: The Barents Sea: Distribution, Sources, Variability and Burial of Organic Carbon, in: The Organic Carbon Cycle in the Arctic Ocean, edited by: Stein, R. and Macdonald, R. W., Springer, Berlin, Heidelberg, 266-278, 2004.

Vorren, T. O., Lebesbye, E., Andreassen, K., and Larsen, K.-B.: Glacigenic sediments on a passive continental margin as exemplified by the Barents Sea, Mar. Geol., 85, 251-272, 1989. 
Wanner, H., Beer, J., Bütikofer, J., Crowley, T. J., Cubasch, U., Flückiger, J., Goosse, H., Grosjean, M., Joos, F., Kaplan, J. O., Küttel, M., Müller, S. A., Prentice, I. C., Solomina, O., Stocker, T. F., Tarasov, P., Wagner, M., and Widmann, M.: Mid- to Late Holocene climate change: an overview, Quaternary Sci. Rev., 27, 1791-1828, doi:10.1016/j.quascirev.2008.06.013, 2008.

Wassmann, P., Bauerfeind, E., Fortier, M., Fukuchi, M., Hargrave, B., Moran, B., Noji, T., Nöthig, E.-M., Olli, K., Peinert, R., Sasaki, H., and Shevchenko, V.: Particulate organic carbon flux to the Arctic Ocean sea floor, in: The organic carbon cycle in the Arctic Ocean, edited by: Stein, R., and Macdonald, R. W., Springer, Berlin, Heidelberg, 101-138, 2004.

Wassmann, P., Reigstad, M., Haug, T., Rudels, B., Carroll, M. L., Hop, H., Gabrielsen, G. W., Falk-Petersen, S., Denisenko, S. G., Arashkevich, E., Slagstad, D., and Pavlova, O.: Food webs and carbon flux in the Barents Sea, Prog. Oceanogr., 71, 232-287, doi:10.1016/j.pocean.2006.10.003, 2006a.

Wassmann, P., Slagstad, D., Riser, C., and Reigstad, M.: Modelling the ecosystem dynamics of the Barents Sea including the marginal ice zone II. Carbon flux and interannual variability, J. Mar. Syst., 59, 1-24, doi:10.1016/j.jmarsys.2005.05.006, 2006b. Wassmann, P., Slagstad, D., and Ellingsen, I.: Primary production and climatic variability in the European sector of the Arctic Ocean prior to 2007: preliminary results, Polar Biol., 33, 16411650, doi:10.1007/s00300-010-0839-3, 2010.
Wassmann, P., Duarte, C. M., AgustÍ, S., and Sejr, M. K.: Footprints of climate change in the Arctic marine ecosystem, Global Change Biol., 17, 1235-1249, doi:10.1111/j.13652486.2010.02311.x, 2011.

Węsławski, J. M., Kędra, M., Przytarska, J., Kotwicki, L., Ellingsen, I., Skardhamar, J., Renaud, P., and Goszczko, I.: A huge biocatalytic filter in the centre of Barents Sea shelf?, Oceanologia, 54, 325-335, doi:10.5697/oc.54-2.325, 2012.

Winkelmann, D. and Knies, J.: Recent distribution and accumulation of organic carbon on the continental margin west off Spitsbergen, Geochem. Geophys. Geosyst., 6, 1-22, doi:10.1029/2005gc000916, 2005.

Winsborrow, M. C. M., Andreassen, K., Corner, G. D., and Laberg, J. S.: Deglaciation of a marine-based ice sheet: Late Weichselian palaeo-ice dynamics and retreat in the southern Barents Sea reconstructed from onshore and offshore glacial geomorphology, Quaternary Sci. Rev., 29, 424-442, doi:10.1016/j.quascirev.2009.10.001, 2010.

Zaborska, A., Carroll, J., Papucci, C., Torricelli, L., Carroll, M. L., Walkusz-Miotk, J., and Pempkowiak, J.: Recent sediment accumulation rates for the Western margin of the Barents Sea, Deep Sea Res. II. 55, 2352-2360, doi:10.1016/j.dsr2.2008.05.026, 2008. 